\title{
Antioxidant Properties and Transepithelial Transportation of Di-/tripeptides Derived from Simulated Gastrointestinal Digestion of Pig Blood Cells Hydrolysates
}

\author{
Xiaojun Ni, Zhenya Zhai, Zhongquan Xin, Chengquan Tan, Yiliang Chen, Jinping Deng, Pinfeng Liao, \\ Limeng Zhang, Zaili Xiao, Baichuan Deng \\ Guangdong Laboratory for Lingnan Modern Agriculture, College of Animal Science, South China Agricultural University, Guangzhou, China \\ National Engineering Research Center for Breeding Swine Industry, College of Animal Science, South China Agricultural University, \\ Guangzhou, China \\ National Engineering Laboratory for Pollution Control and Waste Utilization in Livestock and Poultry Production, College of Animal Science, \\ South China Agricultural University, Guangzhou, China \\ Guangdong Provincial Key Laboratory of Animal Nutrition Control, College of Animal Science, South China Agricultural University, \\ Guangzhou, China \\ Subtropical Institute of Animal Nutrition and Feed, College of Animal Science, South China Agricultural University, Guangzhou, China
}

\section{ARTICLE INFO}

\section{Article History}

Received 12 March 2020

Accepted 21 April 2020

\section{Keywords}

Pig blood cells

di-/tripeptides

antioxidant activity

transepithelial transportation

Caco-2 cells

\section{ABSTRACT}

Pig blood is an important by-product of the meat industry, which has not been fully utilized. In this study, Pig Blood Cells (PBC) were hydrolyzed by Alcalase and followed with simulated Gastrointestinal (GI) digestion to generate bioactive peptides. The antioxidant properties and the intestinal epithelial cells permeabilities of di-/tripeptides from PBC Hydrolysates (PBCH) were investigated. PBCH showed higher 1,1-diphenyl-2-picrylhydrazy and 2,2'-Azino-bis(3-ethylbenzothiazoline-6-sulphonic acid) radical scavenging activities than $\mathrm{PBC}$, although the activities were weakened by GI digestion. Besides, both $\mathrm{PBCH}$ and GI digested $\mathrm{PBCH}$ (PBCH-GI) significantly improved cell viability and suppressed the production of reactive oxygen species under oxidative stress conditions in Caco-2 cells. By using ultra performance liquid chromatography-orbitraptandem-mass spectrometry (UPLC-Orbitrap-MS/MS) technique, 5, 144, and $150 \mathrm{di}$-/tripeptides sequences were characterized in the PBC, $\mathrm{PBCH}$ and $\mathrm{PBCH}-\mathrm{GI}$ groups, respectively. The transepithelial transportation revealed that the permeability of di-/tripeptides through intestinal epithelial cells varied from $0.48 \%$ to $10.80 \%$, and the peptides SDL, GDL, KF, FE exhibit high permeability values of $10.80 \%, 10.62 \%, 8.79 \%$ and $7.54 \%$, respectively. These results indicate that $\mathrm{PBCH}$ has strong antioxidant properties and contains absorbable di-/tripeptides, which is promising for functional food additive.

\section{GRAPHICAL ABSTRACT}

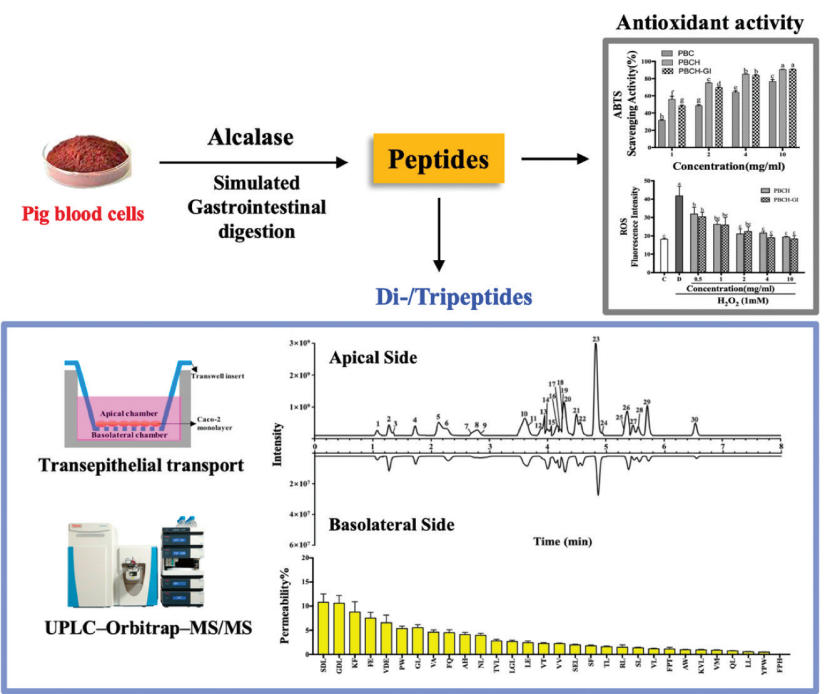

(C) 2020 International Association of Dietetic Nutrition and Safety. Publishing services by Atlantis Press International B.V. This is an open access article distributed under the CC BY-NC 4.0 license (http://creativecommons.org/licenses/by-nc/4.0/). 


\section{INTRODUCTION}

Pig blood is an abundant by-product produced in the slaughtering process. Tons of Pig Blood Cells (PBC) are discarded as waste every year, which is not only a large waste of resources but also a big pollution to the environment [1]. Pig blood contains a valuable source of proteins, among which hemoglobin is a major protein rich in $\mathrm{PBC}$ [2]. It has been reported that enzymatic hydrolysis of $\mathrm{PBC}$ can reduce the bitterness and increase the flavor, owning to the taste attributes of diverse peptides [3]. In addition, peptides derived from PBC show various bioactive functions, such as antioxidant [4], antihypertensive [5], and antimicrobial [6]. Therefore, the study of peptides in PBC hydrolysates on their bioactivities and nutritional values has drawn much attention.

The Gastrointestinal (GI) tract is the major barrier for oral administration of peptides due to the existence of digestive enzymes [7]. On the other hand, GI digestion has reported to generate bioactive peptides [8]. Hence, digestive behavior of bioactive peptides provides valuable information on their actual functions in vivo. In recent studies, simulated GI digestion has been widely used to quickly and efficiently evaluate peptide activity and stability of hydrolysates [9].

Antioxidant peptides are one of the most important outcomes from PBC Hydrolysates (PBCH) [6]. They can inhibit the production of superfluous Reactive Oxygen Species (ROS) to prevent the damage of cellular lipids and proteins and the occurrence of various diseases $[10,11]$. Previously studies have shown that tetrapeptide ADGF, AGGF and ETTL exhibited high radical scavenging ability [10], and peptides NPYVPY and AVPYPQY have been reported to reduce the ROS levels in oxidatively damaged cells [12]. However, studies of these antioxidant peptides mainly focused on peptides with more than three amino acid residues. The antioxidative activity of peptides is affected by many factors, such as their structure and amino acids composition [13]. Studies have indicated that antioxidant peptides with low molecular weight exhibit higher antioxidant activity than large molecular weight peptides [14]. Therefore, it is necessary to investigate the antioxidant activity of low molecular weight peptides derived from PBC.

Small peptides, especially di-/tripeptides, have advantages on intestinal absorption capacity and stability against gastrointestinal proteases over polypeptides [15]. It has been pointed out that di-/tripeptides can be absorbed as intact form into the blood circulation and then produce biological effects [16]. Di-/tripeptides can be transported by $\mathrm{H}^{+}$coupled Peptide Transporter 1 (PepT1) and be absorbed by intestinal epithelial cells [17]. Most of di-/tripeptides are hydrolyzed into amino acids when cross the intestinal epithelial cells, while others maintain the intact form. However, the permeability of different di-/ tripeptides are still lack of investigation. Human colon adenocarcinoma (Caco-2) cells has commonly been used as a model to evaluate the intestinal permeability of nutraceuticals as well as peptides [12].

In this study, PBC were hydrolyzed by Alcalase to generate di-/ tripeptides. Antioxidant activities of hydrolysates were determined after enzymatic hydrolysis and simulated GI digestion, and the di-/tripeptides from hydrolysates were identified by ultra performance liquid chromatography-orbitraptandem-mass spectrometry (UPLC-Orbitrap-MS/MS). Then, the transepithelial transport experiments were carried out to investigate the permeability of di-/ tripeptides. The aim of this study is to investigate antioxidant properties and transepithelial transportation of di-/tripeptides derived from simulated GI digestion of $\mathrm{PBCH}$.

\section{MATERIALS AND METHODS}

\subsection{Materials}

Alcalase from Bacillus licheniformis (200 U/mg) was purchased from Shanghai Yuanye Bio-Technology Co., Ltd. (Shanghai, China). Pepsin from porcine stomach, trypsin from porcine pancreas and L-Methionine sulfone (purity $\geq 99 \%$ ) were all obtained from J\&K Scientific Ltd. (Beijing, China). 1,1-Diphenyl-2-picrylhydrazy (DPPH), Methylthiazolyldiphenyl-tetrazolium bromide (MTT), $2^{\prime}, 7^{\prime}$-Dichlorofluorescin Diacetate (DCFH-DA) and formic acid (liquid chromatography-mass spectrometry (LC-MS) grade) were purchased from Sigma-Aldrich (St. Louis, MO, USA). The 2,2'22 ich (St. Louis, MO, USA). olium bromide (MTT), 2'(ABTS) total antioxidant capacity assay kit was purchased from Beyotime Institute of Biotechnology (Shanghai, China). Standard substances of dipeptides (purity $\geq 95 \%$ ) were obtained from DGpeptidesCo., Ltd. (Hangzhou, China). Caco-2 cells were obtained from the American Type Culture Collection (Manassas, VA, USA). Dulbecco's Modified Eagle Medium/Nutrient Mixture F-12 (DMEM/F12), Fetal Bovine Serum (FBS), Hanks' Balanced Salt Solution (HBSS) and antibiotic solution (10,000 units/mL penicillin, $10,000 \mu \mathrm{g} / \mathrm{mL}$ streptomycin) were purchased from Gibco Life Technologies (Grand Island, NY, USA). Hydrogen peroxide $\left(\mathrm{H}_{2} \mathrm{O}_{2}\right)$ was purchased from Guangzhou Chemical Reagent Factory (Guangzhou, China). Acetonitrile (ACN, LC-MS grade), methanol (high performance liquid chromatography (HPLC) grade) were purchased from Merck (Darmstadt, Germany).

\subsection{Sample Preparation}

Fresh pig blood was obtained from the Institute of Subtropical Agriculture, the Chinese Academy of Sciences (Changsha, China). The collected fresh blood was mixed with sodium citrate $(10 \mathrm{~g} / \mathrm{L})$ to prevent clotting, then centrifuged at $4000 \mathrm{~g}$ at $4^{\circ} \mathrm{C}$ for $15 \mathrm{~min}$ to obtain the blood cell fractions. The red blood cells were formed the bottom layer after centrifugation, then harvested and lyophilized by a vacuum freeze dryer. Freeze-dried PBC were dissolved with distilled water (20 $\mathrm{mg} / \mathrm{mL}$ ), hydrolyzed by Alcalase in optimized conditions (Enzyme/ Substrate $2.5 \%, \mathrm{pH} 10,40^{\circ} \mathrm{C}, 30 \mathrm{~h}$ ) to obtain hydrolysates. $\mathrm{pH}$ was adjusted with $1 \mathrm{M} \mathrm{NaOH}$ or $\mathrm{HCl}$. After the reaction, hydrolysates were heated to inactivate the enzyme at $90^{\circ} \mathrm{C}$ for $15 \mathrm{~min}$, then centrifuged at $8000 \mathrm{~g}$ for $10 \mathrm{~min}$ at $4^{\circ} \mathrm{C}$ to remove the precipitates. The supernatants were collected, lyophilized, and stored at $-20^{\circ} \mathrm{C}$ for further analysis.

\subsection{Optimization of Sample Preparative Conditions}

Response Surface Methodology (RSM) was used to optimize enzymatic hydrolysis conditions according to the Degree of Hydrolysis $(\mathrm{DH})$ of $\mathrm{PBC}$. DH is an important indicator during protein hydrolysis, which is defined as the percentage of cleaved peptide bonds [18]. The four independent variables, i.e. time, $\mathrm{pH}$, temperature and Enzyme-to-Substrate Ratio (E/S) at three different levels were applied in a Box-Behnken Design (BBD) of RSM. Table S1 shows the levels of the independent variables. Design-Expert (Version 8.0.6, Stat-Ease. Inc., Minneapolis, MN, USA) software was applied to analyze the experimental data, establishing the quadratic regression equation and determining the optimal combination of hydrolysis conditions. Experimental validation was performed using the 
optimized condition to ensure the validity of RSM model. The DH was measured according to the $o$-phthaldialdehyde method [18].

\subsection{Simulated Gastrointestinal (GI) Digestion}

Gastrointestinal digestion of $\mathrm{PBCH}$ was performed by the method of Cinq-Mars et al. [19] with slight modifications. Briefly, the $\mathrm{PBCH}$ solution was digested by pepsin (E/S, 1:35, w/w) for $1 \mathrm{~h}$ at $37^{\circ} \mathrm{C}, \mathrm{pH} 2.0$. Then, $\mathrm{pH}$ was adjusted to 5.3 with $\mathrm{NaHCO}_{3}$ and further to 7.5 with $1 \mathrm{M} \mathrm{NaOH}$. Trypsin (E/S, 1:25, w/w) was added to hydrolysates for further digestion, incubated at $37^{\circ} \mathrm{C}$ for $2 \mathrm{~h}$. After centrifugation at $10,000 \mathrm{~g}$ for $10 \mathrm{~min}$, the supernatants were lyophilized and stored at $-20^{\circ} \mathrm{C}$.

\subsection{DPPH Radical Scavenging Activity}

The DPPH radical scavenging activity was determined according to the method of Brand-Williams et al. [20] with some modifications. Samples were dissolved in sodium phosphate buffer to obtain various concentrations $(1,2,4$ and $10 \mathrm{mg} / \mathrm{mL})$. About $100 \mu \mathrm{L}$ sample solution was mixed with $100 \mu \mathrm{L}$ DPPH solution $(0.1 \mathrm{M}$ in 95\% ethanol) in each well of the 96-well microplates. After incubation for $30 \mathrm{~min}$, the absorbance was measured at $517 \mathrm{~nm}$ using a multimode microplate reader (VarioskanTM LUX, Thermo Fisher Scientific, MA, USA). The DPPH radical scavenging activity was calculated using the following equation:

$\mathrm{DPPH}$ radical scavenging activity $(\%)=\left[1-\left(\frac{S-S_{\mathrm{b}}}{C-C_{\mathrm{b}}}\right)\right] \times 100$

where $C$ is the absorbance of buffer solution plus DPPH solution, $C_{\mathrm{b}}$ is the absorbance of buffer solution plus ethanol, $S$ is the absorbance of the sample mixed with DPPH solution and $S_{\mathrm{b}}$ is the absorbance of the sample plus ethanol.

\subsection{ABTS Radical Scavenging Activity}

The ABTS radical scavenging activity was performed using the total antioxidant capacity assay kit with ABTS method. The ABTS radical cation $\left(\mathrm{ABTS}^{+}\right)$solution was produced by mixing ABTS stock solution with $2.45 \mathrm{mM}$ potassium persulfate for $12-16 \mathrm{~h}$ in the dark at room temperature. Then, the $\mathrm{ABTS}^{+}$solution was diluted with sodium phosphate buffer to reach an absorbance of $0.70 \pm 0.05$ at $734 \mathrm{~nm}$. About $10 \mu \mathrm{L}$ sample solution was added to $200 \mu \mathrm{L}$ of diluted $\mathrm{ABTS}^{+}$solution, the absorbance was measured at $734 \mathrm{~nm}$ after 2-6 min incubation in the dark at room temperature. Buffer solution without the addition of sample was used as the blank. The ABTS radical scavenging activity was calculated using the following equation:

ABTS radical scavenging activity $(\%)=\left[1-\left(\frac{A_{\mathrm{s}}}{A_{\mathrm{b}}}\right)\right] \times 100$

where $A_{\mathrm{s}}$ is the absorbance of the sample and $A_{\mathrm{b}}$ is the absorbance of the blank.

\subsection{Cell Viability Assay}

Caco- 2 cells were cultured in DMEM/F12 supplemented with $10 \%$ FBS and $1 \%$ antibiotic solution, at $37^{\circ} \mathrm{C}$ under $5 \% \mathrm{CO}_{2}$, fully humidified atmosphere. The medium was changed every other day. Cell viability was determined by the MTT method [21]. Briefly, Caco-2 cells were seeded in 96-well plates at a density of $1 \times 10^{4}$ cells/well and incubated for $24 \mathrm{~h}$ at $37^{\circ} \mathrm{C}, 5 \% \mathrm{CO}_{2}$. Then, cells were treated with different hydrolysates concentrations of samples at $0.5,1,2,4$ and 10 $\mathrm{mg} / \mathrm{mL}$. The control cells were treated with medium only. After 24 $\mathrm{h}$ incubation, MTT $(5 \mathrm{mg} / \mathrm{mL})$ was added, and cells were continued to culture for $4 \mathrm{~h}$. About $150 \mu \mathrm{L}$ dimethyl sulfoxide was added to dissolve the formed formazan, after 30 min shaking at room temperature, the absorbance was measured at a wavelength of $490 \mathrm{~nm}$.

\subsection{Intracellular Reactive Oxygen Species Levels}

The intracellular ROS scavenging capacity of PBCH and PBCH-GI in oxidized Caco- 2 cells were measured using a DCFH-DA fluorescent probe assay, following the method of Wang et al. [22]. Caco- 2 cells at the density of $1 \times 10^{4}$ cells/well were seeded onto 96-well plates and incubated for $24 \mathrm{~h}$. Then, cells were pretreated with $180 \mu \mathrm{L} /$ well of $\mathrm{PBCH}$ and PBCH-GI at final concentrations of $0.5-10 \mathrm{mg} / \mathrm{mL}$, for another $24 \mathrm{~h}$. About $1 \mathrm{mM} \mathrm{H}_{2} \mathrm{O}_{2}$ was added to cells for further $2 \mathrm{~h}$ to induce oxidative stress. Cell viability was determined using the MTT method. For determination of intracellular ROS level, cells were incubated with $100 \mu \mathrm{L}$ of $100 \mu \mathrm{M}$ DCFH-DA for $30 \mathrm{~min}$. The control cells were treated with medium only and damaged cells were added with medium and $\mathrm{H}_{2} \mathrm{O}_{2}$ only. Finally, the intensity of fluorescence was measured at an excitation wavelength of $488 \mathrm{~nm}$ and an emission wavelength of $525 \mathrm{~nm}$ using a microplate reader. Data was obtained from three independent experiments, with each plate containing six replicates for each sample.

\subsection{Transportation Experiments}

Caco-2 cells were seeded onto 24 -well Transwell inserts $(0.4 \mu \mathrm{m}$ pore size, $6.5 \mathrm{~mm}$ diameter, $0.33 \mathrm{~cm}^{2}$ grown surface, Corning, NY, USA) at a density of $5 \times 10^{5}$ cells/well. The culture medium was carefully replaced until the cells were fully differentiated for at least 21 days. The integrity of cells monolayer was measured by measuring Transepithelial Electrical Resistance (TEER) using a Millicell ERS-2 epithelial volt-ohm meter (Millipore, Billerica, MA, USA), and only monolayers with TEER value above $300 \Omega \cdot \mathrm{cm}^{2}$ were used for the transport study. Before the transport study, cells were washed twice with HBSS and further equilibrated with $\mathrm{HBSS}$ at $37^{\circ} \mathrm{C}$ for $30 \mathrm{~min}$. Then, $200 \mu \mathrm{L}$ of hydrolysates $(10 \mathrm{mg} / \mathrm{mL})$ dissolved in HBSS was added to the apical side and $600 \mu \mathrm{L}$ of fresh HBSS added to the basolateral side. After $2 \mathrm{~h}$ of incubation, the remnants on the Apical Side (AP) and the absorbed permeates on the Basolateral Side (BL) were collected for UPLC-Orbitrap-MS/MS analysis. The permeability of small peptide from hydrolysates was calculated according to the following equation:

$$
\text { Permeability }(\%)=\left[\frac{C_{\mathrm{b}}}{\left(C_{0}-C_{\mathrm{a}}\right)}\right] \times 100
$$


where $C_{\mathrm{b}}$ is the small peptide contents detected in the BL after $2 \mathrm{~h}$ transport. $C_{0}$ and $C_{\mathrm{a}}$ are the small peptide contents detected in the $\mathrm{AP}$ before and after $2 \mathrm{~h}$ transport, respectively.

\subsection{UPLC-Orbitrap-MS/MS Analysis}

The samples were thawed at room temperature. To precipitate proteins, $1 \mathrm{~mL}$ methanol were added to $180 \mu \mathrm{L}$ samples with $50 \mu \mathrm{L}$ L-methionine sulfone (10 $\mu \mathrm{g} / \mathrm{mL}$, internal standard), vortexed and then centrifuged at $14,500 \mathrm{rpm}$ for $15 \mathrm{~min}$ at $4^{\circ} \mathrm{C}$. The supernatants were evaporated and reconstituted in $200 \mu \mathrm{L}$ methanol, then filtered through a $0.22-\mu \mathrm{m}$ regenerated cellulose filter before UPLCOrbitrap-MS/MS analysis. The di-/tripeptides in samples were analyzed by a Dionex UltiMate 3000 UPLC system coupled with a high-resolution Q-Exactive Focus mass spectrometer (Thermo Fisher Scientific, MA, USA). The chromatographic separation was performed on a $\mathrm{C}_{18}$ Hypersil Gold column $\left(100 \times 2.1 \mathrm{~mm}^{2}, 1.9 \mu \mathrm{m}\right.$, Thermo Fisher Scientific, MA, USA). The mobile phase was $0.1 \%$ formic acid in water (A) and acetonitrile (B), setting a flow rate of $0.2 \mathrm{~mL} / \mathrm{min}$. Gradient elution started with $5 \% \mathrm{~B}$ and increased to $95 \%$ B in 15 min. The composition was then held at $95 \%$ B for $5 \mathrm{~min}$ and returned to initial conditions. The injection volume was $2 \mu \mathrm{L}$. The mass spectrometer data were obtained using heated Electrospray Ionization (ESI) in the positive ionization modes, spray voltage, $4 \mathrm{kV}$ (+4 kV in ESI+), $3 \mathrm{kV}(-3 \mathrm{kV}$ in ESI-); sheath gas $\left(\mathrm{N}_{2},>95 \%\right), 30$ bar; auxiliary gas, 10 bar; heater temperature, $350^{\circ} \mathrm{C}$; capillary temperature, $320^{\circ} \mathrm{C}$. Full MS scan ranged from $\mathrm{m} / z$ 100 to 1000 at the resolution of 35,000. The MS/MS scanning mode performed at the resolution of 17,500 and high collision-induced dissociation was set as stepped normalization collision energy mode $(10,30,50)$. Xcalibur 3.0 (Thermo Fisher Scientific, MA, USA) was used for UPLC-Orbitrap-MS/MS control and data analysis.

\subsection{Identification and Quantification of Di-/tripeptides}

The raw data including the information of retention time, exact mass, MS and MS/MS spectra were generated by UPLC-OrbitrapMS/MS. These information of di-/tripeptides were extracted by Xcalibur 3.0 and used to identify was based on the following: (a) by comparing the 400 dipeptides standard substance in terms of retention time, exact mass and MS/MS spectra. (b) By searching the online database MyCompoundID (www.mycompoundid.org/ PEP), which consisting of predicted MS/MS spectra of 400 dipeptides and 8000 tripeptides [23]. The characteristic fragmentation pathways of di-/tripeptides were described and analyzed with the help of Chemdraw (version 12.0, PerkinElmer, USA) to verify and identify peptides. Quantification of di-/tripeptides were performed using the internal standard method. The quantitative results of di-/tripeptides were obtained by calculating the peak area ratio of one peptide to the internal standard on the same chromatogram. The concentration of internal standard (L-methionine sulfone) was $10 \mu \mathrm{g} / \mathrm{mL}$. Porcine hemoglobin (Sus scrofa) sequences were obtained from NCBI protein database (http:// www.ncbi.nlm.nih.gov/). The bioactivities of peptides were obtained by searching the BIOPEP database (http://www.uwm. edu.pl/biochemia/index.php/pl/biopep/) and published literatures $[24,25]$.

\subsection{Statistical Analysis}

MZmine 2.2.1 (open-source software) was used for mass-spectrometry data processing, including the modules of align scans, peak detection, deconvolution, peak list alignment, gap filling and filtering [26,27]. All data were expressed as the mean \pm Standard Deviation (SD), of three independent experiments. Student's $t$-test was applied to determine the differences between two groups of samples with the significance level at $p<0.05$. One-way Analysis of Variance (ANOVA) and Duncan's multiple range test were used to determine the differences among multiple groups of samples with the significance level at $p<0.05$. All statistical analysis was operated by SPSS 23.0 software (SPSS Inc., Chicago, IL, USA), except that the differences of independent variables in BBD design were analyzed using Design-Expert software.

\section{RESULTS AND DISCUSSION}

\subsection{Optimization of Extraction Conditions}

The experimental design and results for the $\mathrm{DH}$ (\%) under various combinations of variables are shown in Table S2. A quadratic regression model was obtained using Design-Expert based on the experimental data. Table S3 displays the ANOVA for response surface quadratic model. The probability value of $\mathrm{DH}$ indicated a high significance for regression equation $(p<0.01)$ and the lack of fit was insignificant. The determination coefficient $\left(R^{2}\right)$ and predicted $R^{2}$ were 0.9821 and 0.9021 , respectively, showing that the model could be used to fit the effect of four factors on the $\mathrm{DH}$ of hydrolysates. The optimal hydrolysis conditions were $\mathrm{E} / \mathrm{S}$ of $2.5 \%(\mathrm{w} / \mathrm{w}), \mathrm{pH}$ of 10 , temperature of $40^{\circ} \mathrm{C}$ and incubation period of $30 \mathrm{~h}$. Under this condition, the $\mathrm{DH}$ of hydrolysates reaches a maximum of $49.19 \%$, which is in reasonable agreement with the predicted value $(49.74 \%)$. Hydrolysates obtained from this condition were used for further studies.

\subsection{Chemical Antioxidant Activities}

In this study, antioxidant properties of the PBC after Alcalase hydrolysis and simulated GI digestion were investigated. DPPH and ABTS radical are stable free radical that can be scavenged by antioxidants, which have been widely used to evaluate antioxidant activity of natural products [28]. The DPPH and ABTS radical scavenging activities of $\mathrm{PBC}, \mathrm{PBCH}$ and $\mathrm{PBCH}-\mathrm{GI}$ are shown in Figure 1. It can be seen from Figure $1 \mathrm{~A}$ that the DPPH radical scavenging activity of $\mathrm{PBCH}$ was significantly improved when compared to $\mathrm{PBC}$, and the activities show a dose-dependent manner. $\mathrm{PBCH}$ had the highest DPPH radical scavenging activity of $72.85 \pm$ $2.00 \%$ at a concentration of $10 \mathrm{mg} / \mathrm{mL}$. In a previous study, porcine hemoglobin was hydrolyzed by Alcalase for $10 \mathrm{~h}$ and the DPPH radical scavenging activity was $48.55 \pm 3.97 \%$ [29]. After treated with fungal protease FP400 for $24 \mathrm{~h}$, the ability of $\mathrm{PBCH}$ to scavenge DPPH radicals was $59.39 \pm 2.43 \%$ [6]. It can be seen that the $\mathrm{DPPH}$ radical scavenging activity of $\mathrm{PBCH}$ in our study was better than that of previous studies by optimizing the hydrolysis conditions of the Alcalase. After simulated GI digestion, the scavenging activity of $\mathrm{PBCH}$ was decreased, and at a concentration of $4 \mathrm{mg} / \mathrm{mL}$ of the hydrolysates, the DPPH radical scavenging activity was reduced by about $8 \%$. This trend was consistent with the results reported on carp protein hydrolysates [30]. And this may be due to 

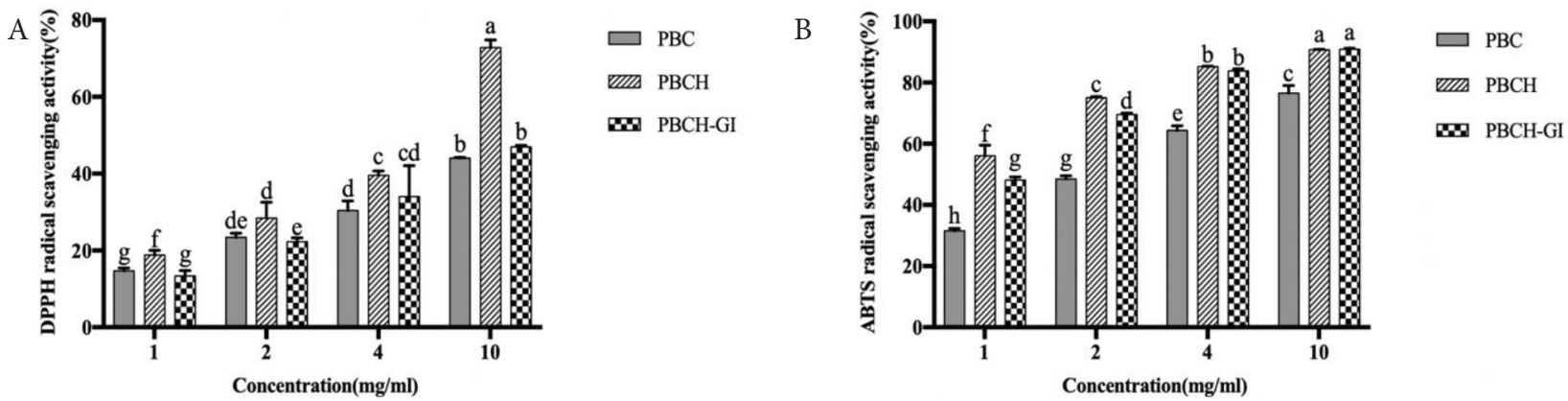

Figure 1 DPPH (A) and ABTS radical scavenging activity (B) of PBC, $\mathrm{PBCH}$ and $\mathrm{PBCH}-\mathrm{GI}$ at various concentrations. Values are expressed as the means $\pm \mathrm{SD}, n=3$; data with different lowercase letters show significant differences $(p<0.05)$. PBC, pig blood cells; PBCH, pig blood cell hydrolysates; PBCH-GI, gastrointestinal-digested pig blood cell hydrolysates.

A

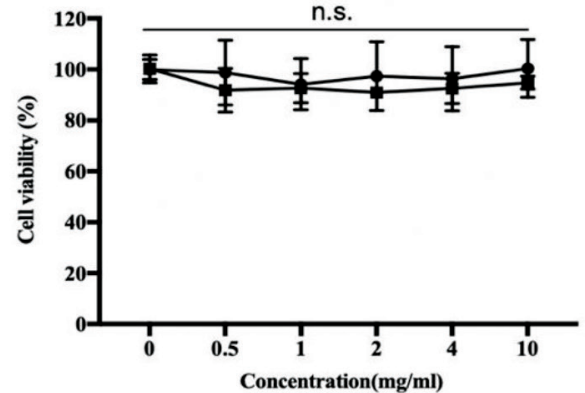

C

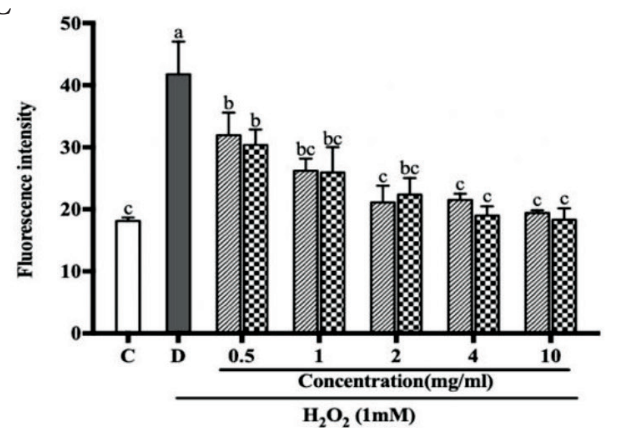

B
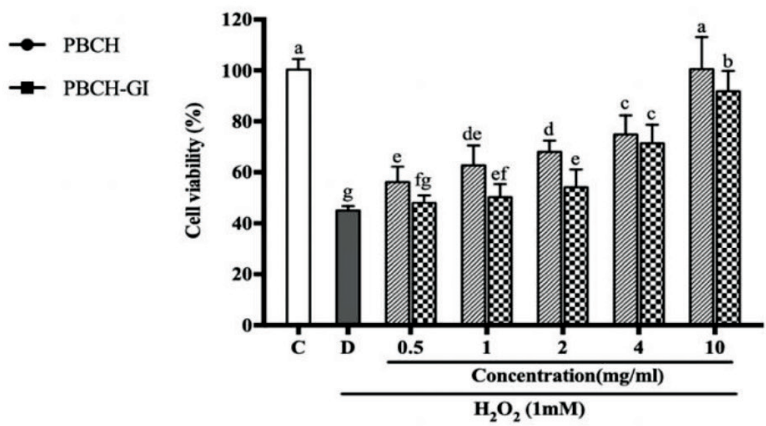

표 $\mathrm{PBCH}$

\$ PBCH-GI
대을 $\mathrm{PBCH}$

冈 PBCH-GI

Figure 2 Effect of PBCH and PBCH-GI on the viability of Caco-2 cells at different concentrations (A). Cytoprotective effects of PBCH and PBCH-GI under conditions of oxidative stress in Caco-2 cells (B). Intracellular ROS scavenging capacities of PBCH and PBCH-GI under conditions of oxidative stress in Caco-2 cells $(C)$. For the oxidative stress assay, the control group $(C)$ was treated with medium alone, and the damaged group (D) was treated with medium and 1 mM $\mathrm{H}_{2} \mathrm{O}_{2}$. Data are expressed as the mean $\pm \mathrm{SD}, n=6$. Bars with different lowercase letters are significantly different $(p<0.05)$. n.s. indicates that there is no significant difference between the groups $(p>0.05)$. PBCH, pig blood cells hydrolysates; PBCH-GI, gastrointestinal-digested pig blood cells hydrolysates.

the degradation of some antioxidant peptides by digestive enzyme into small peptides and amino acids. Figure 1B shows the ABTS radical scavenging activity of the samples, which was evaluated at concentrations from 1 to $10 \mathrm{mg} / \mathrm{mL}$. Compared to $\mathrm{PBC}, \mathrm{PBCH}$ displayed higher radical scavenging activity and the scavenging activities were dependent on the concentration of samples. At the highest concentration of $10 \mathrm{mg} / \mathrm{mL}, \mathrm{PBCH}$ showed $90.75 \pm 0.09 \%$ scavenging effect on ABTS radicals. After GI digestion, there was a significant decrease on the scavenging activity of $\mathrm{PBCH}$ at the concentration of 1 and $2 \mathrm{mg} / \mathrm{mL}$. The results of free radical scavenging activity of hydrolysates are consistent with the former study, which pointed out that the radical scavenging activity of casein peptide fractions and soybean hydrolysates were significantly reduced after simulated GI digestion, and the percentage of decrease was $10 \%$
[31]. The above results demonstrate that $\mathrm{PBCH}$ has positive effects on scavenging free radicals, but the effects are weakened by simulated GI digestion.

\subsection{Cellular Antioxidant Activities}

In addition to common chemical assays for screening antioxidants, it is important to use cell models to evaluate antioxidant activity, which is cost-effective and helpful in predicting in vivo effects of antioxidant peptides [22]. Caco-2 cells were selected to evaluate the antioxidant activities of $\mathrm{PBCH}$ and $\mathrm{PBCH}-\mathrm{GI}$. Before measuring antioxidant capacity, it is necessary to know whether the hydrolysates are toxic to cells. The results show that the $\mathrm{PBCH}$ and $\mathrm{PBCH}-\mathrm{GI}$ have 
no significant difference on cell viability at the test concentrations (Figure $2 \mathrm{~A})$. Then, hydrogen peroxide $\left(\mathrm{H}_{2} \mathrm{O}_{2}\right)$ is used as the oxidative stress stimulus, which can enter the interior of cells and cause the generation of ROS. As can be seen from Figure 2B, the damaged cells group which was added with $1 \mathrm{mM} \mathrm{H}_{2} \mathrm{O}_{2}$, showed lower cell viability than the control group $(p<0.05)$. Nevertheless, pretreatment of cells with $\mathrm{PBCH}$ and $\mathrm{PBCH}-\mathrm{GI}$ significantly increased cell viability when compared to the damaged group $(p<0.05)$, indicating the cytoprotective effect on oxidatively damaged Caco- 2 cells. Besides, the protective effect of $\mathrm{PBCH}$ on $\mathrm{H}_{2} \mathrm{O}_{2}$-induced damaged cells generally decreased after GI digestion. The protective effect of $\mathrm{PBCH}$ and $\mathrm{PBCH}-\mathrm{GI}$ on cells may be related to the clearance of ROS. The intracellular ROS scavenging capacities of PBCH and PBCH-GI under conditions of damaged Caco-2 cells were shown in Figure 2C. The ROS level in Caco-2 cells increased significantly after treatment with $\mathrm{H}_{2} \mathrm{O}_{2}$; however, compared to the damaged group, the treatment of cells with $\mathrm{PBCH}$ and $\mathrm{PBCH}-\mathrm{GI}$ significantly suppressed ROS formation at concentrations ranging from 0.5 to $10 \mathrm{mg} / \mathrm{mL}$. Particularly, when the treatment concentration of hydrolysates was 4 and $10 \mathrm{mg} /$ $\mathrm{mL}$, there was no significant difference in ROS level compared to the control group. Under the treatment of PBCH-GI, the ROS level of cells stimulated by $\mathrm{H}_{2} \mathrm{O}_{2}$ were reduced by $27.27 \%, 37.95 \%, 46.39 \%$, $54.50 \%$ and $56.18 \%$ at concentrations of $0.5,1,2,4$ and $10 \mathrm{mg} / \mathrm{mL}$. In a previous study, the ROS level in $\mathrm{H}_{2} \mathrm{O}_{2}$-stimulated cells of soybean hydrolysate was decreased by $22.74 \%$ at concentrations of $1 \mathrm{mg} /$ $\mathrm{mL}$ [7]. Our results are consistent with the previous reports, which show that milk and corn gluten meal derived antioxidant peptides can effectively scavenge intracellular excess free radicals [12,22]. The results indicate that $\mathrm{PBCH}$ and $\mathrm{PBCH}-\mathrm{GI}$ have strong ROS scavenging capacities on oxidative damaged cells.

\subsection{Identification of Di-/tripeptides from Hydrolysates}

Di-/tripeptides from hydrolysates were analyzed by UPLCOrbitrap-MS/MS. Total Ion Chromatograms (TICs) of PBC, $\mathrm{PBCH}$ and $\mathrm{PBCH}-\mathrm{GI}$ were shown in Figure 3. The TICs profiles of $\mathrm{PBCH}$ and $\mathrm{PBCH}-\mathrm{GI}$ were very similar, but very different from PBC (Figure 3A-3C). PBCH and PBCH-GI showed more peaks in the TICs than PBC. Di-/tripeptides were identified by comparing the retention time, exact mass and MS/MS spectra with standard substances or searching the online database. In order to understand the fragmentation process of di-/tripeptides, the MS/MS spectra and possible fragmentation pathways of dipeptide AW and tripeptide YPW were in Figure 4. During the collision cracking process, the main characteristic fragment ions of dipeptide AW were $\mathrm{m} / z$ 188.0704, 205.0970, 146.0599, 276.1340, 189.0740. For tripeptide YPW, the characteristic fragment ions were $\mathrm{m} / \mathrm{z} 70.0658,465.2130$, $302.1496,136.0756,188.0704$. It can be seen that the characteristic fragmentation pathway further confirms the identification of di-/tripeptides. Table S4 summarizes the information of all identified and tentatively identified di-/tripeptides from hydrolysates, including peptide sequence, retention time, accurate $\mathrm{m} / z$ value, and the major MS/MS fragment. All the detected di-/tripeptides can be found in the alpha and beta subunit of porcine hemoglobin. In total, there were 5, 144 and $150 \mathrm{di}$-/tripeptides sequences characterized in the $\mathrm{PBC}, \mathrm{PBCH}$ and $\mathrm{PBCH}-\mathrm{GI}$, respectively. Five dipeptides identified in PBC with the sequence of VL, NL, DL, EL and FP were also found in $\mathrm{PBCH}$ and $\mathrm{PBCH}-\mathrm{GI}$. Six di-/tripeptides, i.e. AHK, ERM, ESF, FAK, GR and SV, were identified solely in $\mathrm{PBCH}-\mathrm{GI}$. These results show that the number of di-/tripeptides increased greatly after Alcalase hydrolysis. It may be due to the wide cleavage sites in Alcalase, which leads to the protein broken down. As expected, the number of di-/tripeptides was further increased after simulated GI digestion, which may be attributed to the degradation of macromolecular peptides into smaller peptides under the hydrolysis of digestive enzymes. Previous study has found that the $\mathrm{DH}$ of pig hemoglobin was increased after flavourzyme hydrolysis, coupling with a more complex chromatogram [29]. It is well known that $\mathrm{DH}$ indicates the degree of cleaved peptide bonds during proteolysis, and the higher the $\mathrm{DH}$, the smaller peptides are released from hydrolysates. From the TICs plot (Figure 3A-3C), we also found that the chromatogram of hydrolysates is more complicated than that before hydrolysis, which may be related to the abundant small peptides in the hydrolysates.

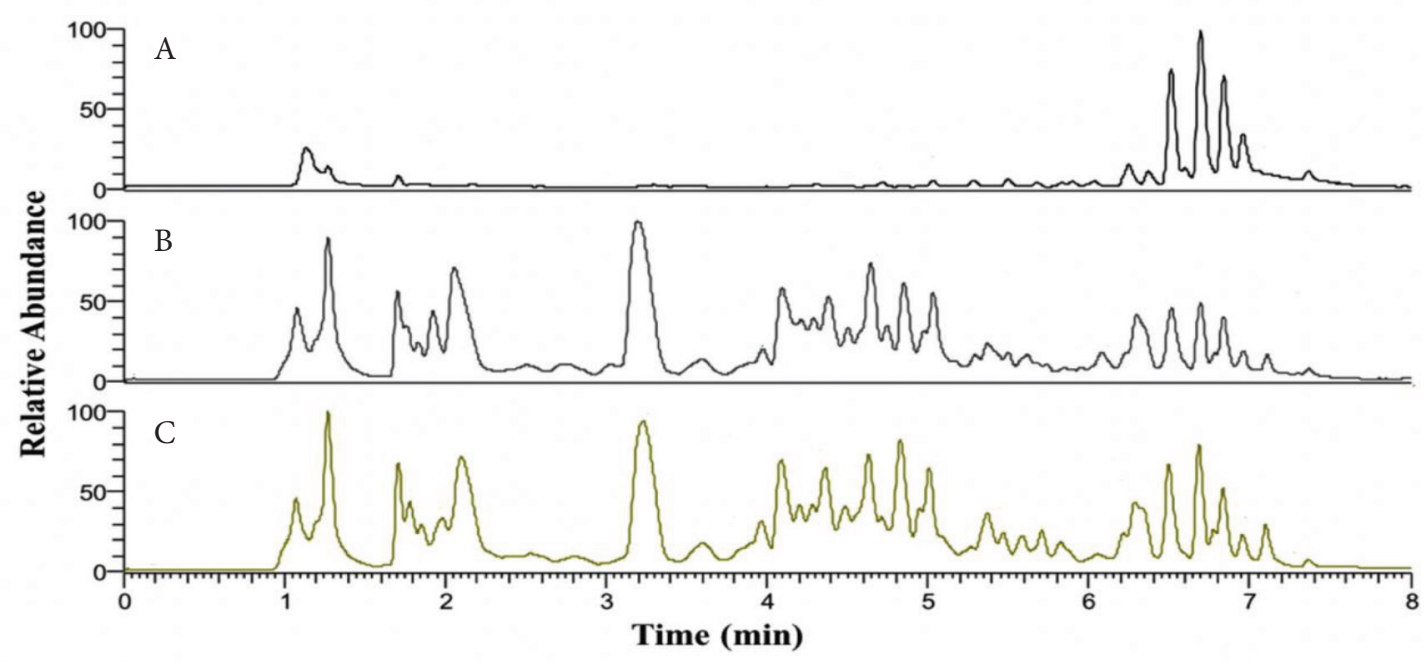

Figure 3 Total ion chromatograms of PBC (A), PBCH (B), PBCH-GI (C). PBC, pig blood cell; PBCH, pig blood cell hydrolysates; PBCH-GI, gastrointestinal-digested pig blood cell hydrolysates. 
A

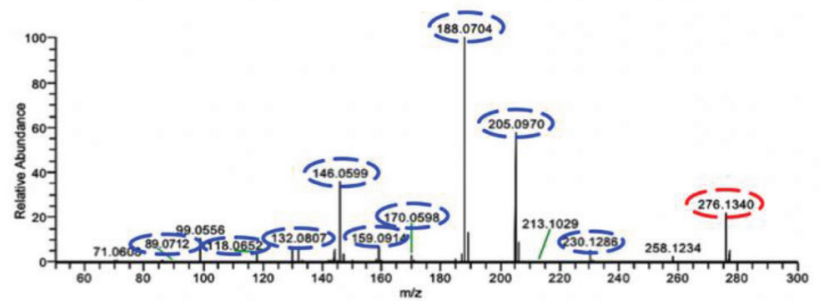

B
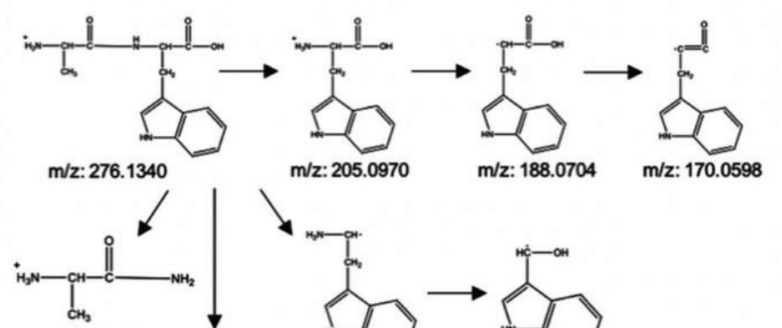

4
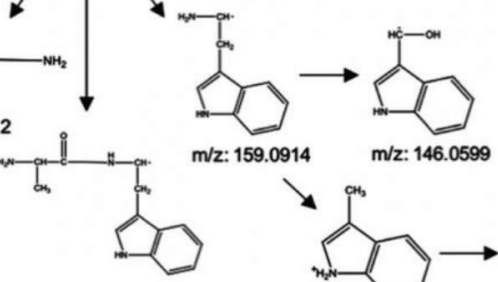

m/z: 230.1286

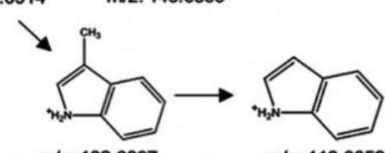

m/z: 132.0807
C

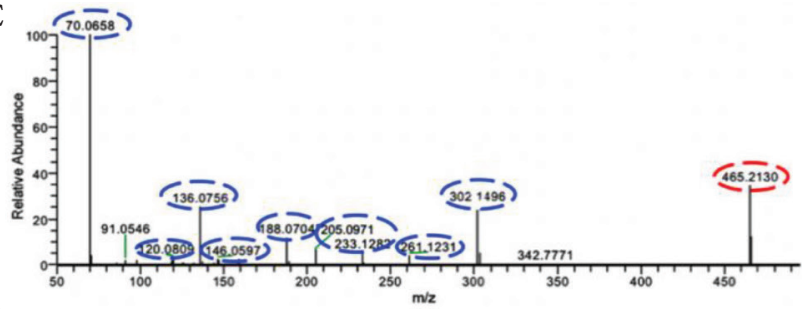

$\mathrm{D}$

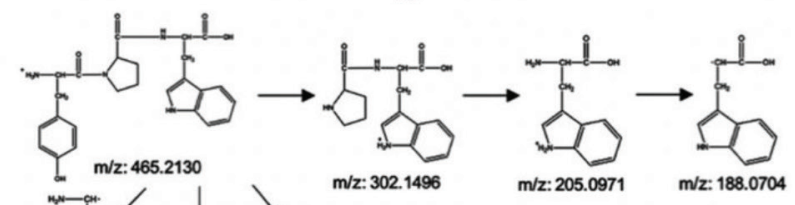<smiles>C1CCC2CCCC2C1</smiles>

m/z: $120.0809 \quad m / z: 261.1231$

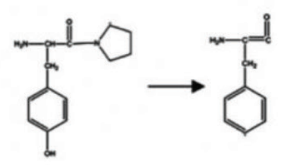

$m / 2: 233.1282 \quad m / z: 146.0597$

Figure 4 Identification of di-/tripeptides. The MS/MS spectra of the AW dipeptide (A) and the YPW tripeptide (C). The potential fragmentation pathways of the AW dipeptide (B) and the YPW tripeptide (D). The precursor ions and fragment ions are indicated by red and blue circles, respectively.

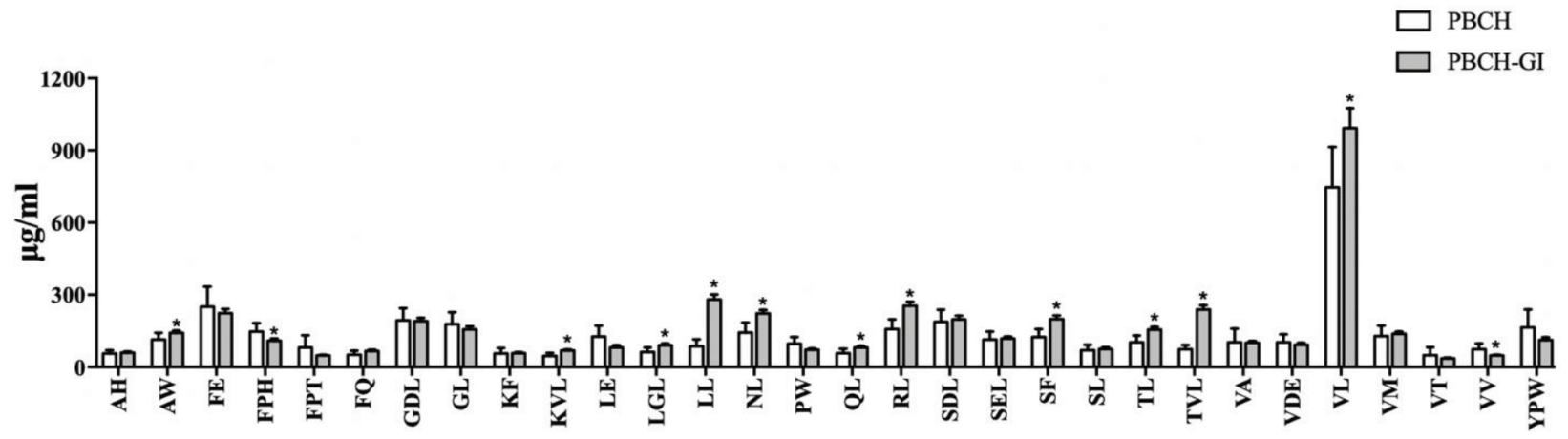

Figure 5 Comparative analysis of major di-/tripeptides in $\mathrm{PBCH}$ before and after GI digestion. Data are expressed as the mean $\pm \mathrm{SD}, n=6 .{ }^{*}$ indicates $p<0.05$ between PBCH and PBCH-GI. PBCH, pig blood cell hydrolysates; PBCH-GI, gastrointestinal-digested PBCH.

\subsection{Quantitative Analysis of Di-/tripeptides from Hydrolysates}

The quantitative results of 150 di-/tripeptides identified in $\mathrm{PBCH}$ and PBCH-GI were also displayed in Table S4. The relative quantification of di-/tripeptides were performed using the internal standard method. In order to compare the difference in the concentration of di-/tripeptides before and after GI digestion, 30 major di-/tripeptides identified from hydrolysates were selected for further analysis. The total content of $30 \mathrm{di}$-/tripeptides accounted for $78.24 \%$ of all identified di-/tripeptides in $\mathrm{PBCH}$. The concentration of 30 di-/tripeptides in $\mathrm{PBCH}$ and PBCH-GI were 3886.79 and $4546.61 \mu \mathrm{g} / \mathrm{mL}$, respectively. By comparing different molecular weight distributions of peptide fractions from casein after GI digestion, researchers found the percentage of $<1000$ Da peptides increased at the end of GI digestion [31]. Our results are consistent with this report. It can be seen from Figure 5 that after GI digestion, the concentration of di-/tripeptides FPH and VV were decreased, and the concentration of di-/tripeptides AW, KVL, LGL,
LL, NL, QL, RL, SF, TL, TVL and VL were significantly increased. The concentration of other di-/tripeptides did not change significantly after GI digestion. The results suggest that most of these di-/tripeptides can resist to gastrointestinal digestion. These results are consistent with the former study, which reported that peptides derived from soybean proteins prepared by thermolysin were highly resistance to pepsin and trypsin, and these peptides were mainly dipeptides and tripeptides [32].

\subsection{Transepithelial Transport of Di-/tripeptides}

For the transport experiment, Caco-2 monolayers were used to evaluate the intestinal absorption of di-/tripeptides from PBCH-GI. The TEER values were measured to ensure the viability and integrity of cells monolayers. Figure 6A displays the chromatograms of PBCH-GI before and after $2 \mathrm{~h}$ transport. Most di-/tripeptides in $\mathrm{PBCH}-\mathrm{GI}$ were observed in the basolateral side of the cell 
monolayers. In Figure 6A, we have labeled the peak positions of 30 major di-tripeptides on the chromatogram, which were marked with the numbers 1-30. All the 30 major di-/tripeptides, except for $\mathrm{FPH}$, were detected in the basolateral side (Figure 6A). Previous research have pointed out that di-/tripeptides can be transported intact through the intestinal epithelium cells [33], which is confirmed in our study. After $2 \mathrm{~h}$ transport, the permeability of the 30 major di-/tripeptides from hydrolysates were shown in Figure 6B. It can be seen that the permeability of most di-/tripeptides is below $10 \%$, which suggests that most di-/tripeptides may be utilized by cells or hydrolyzed into amino acids by multiple cytosolic hydrolases during the transport process. The peptides with highest permeability are SDL, GDL, KF, FE, with the permeability values of $10.80 \%, 10.62 \%, 8.79 \%$ and $7.54 \%$, respectively. In addition, different di-/tripeptides were found to have different permeability through the enterocytes. In a previous study, the permeability of peptides fractions isolated from cooked chicken muscles was calculated to be about $1.0 \%$ [34]. The reported permeability of the casein-derived peptide fractions (MW $<500 \mathrm{Da}$ ) was $16.23 \%$, and the permeability of the four synthetic peptides were IE $44.81 \%$, SDK $21.68 \%$, IV 9.50\% and YPY 5.56\%, respectively [35]. It can be seen from the results that the permeability of peptides is varied, which may be due to their different amino acid compositions. Study have indicated that the hydrolysis and transport of intact di-/tripeptides are highly variable and structure-dependent, and dipeptides with more hydrophobic residues such as Trp, Phe, Leu, or Val mostly showed rapid cleavage, whereas dipeptides containing Gly residues displayed high hydrolysis resistance [33]. And the specific reasons for the different permeability of different di-/ tripeptides need further study. The bioactive activities of the di-/ tripeptides from basolateral permeates were searched from the database of bioactive peptides (BIOPEP) and related published literatures [25]. The bioactive activities of these di-/tripeptides can be seen from Table 1, in which GDL, AH, PW and AW have antioxidant properties. The four antioxidant di-/tripeptides were transported intact through the Caco- 2 cells monolayers, with the permeability of $10.62 \%, 4.10 \%, 5.35 \%$ and $0.96 \%$, respectively. Some other di-/tripeptides have also been reported to have activities such as Angiotensin-converting Enzyme (ACE) inhibitory activity and dipeptidyl peptidase-IV inhibitory activity.

\section{CONCLUSION}

Pig blood cells hydrolysates display strong antioxidant properties, especially the scavenging effect on chemical free radicals and decreased ROS levels under conditions of oxidative stress in Caco- 2 cells. After simulated GI digestion, the scavenging activities of $\mathrm{PBCH}$ were decreased. Di-/tripeptides from $\mathrm{PBC}, \mathrm{PBCH}$ and $\mathrm{PBCH}-\mathrm{GI}$ were accurate identified by UPLC-Orbitrap-MS/ MS, which showed high resistance to GI digestion. Additionally, the permeability of di-/tripeptides through intestinal epithelial cells

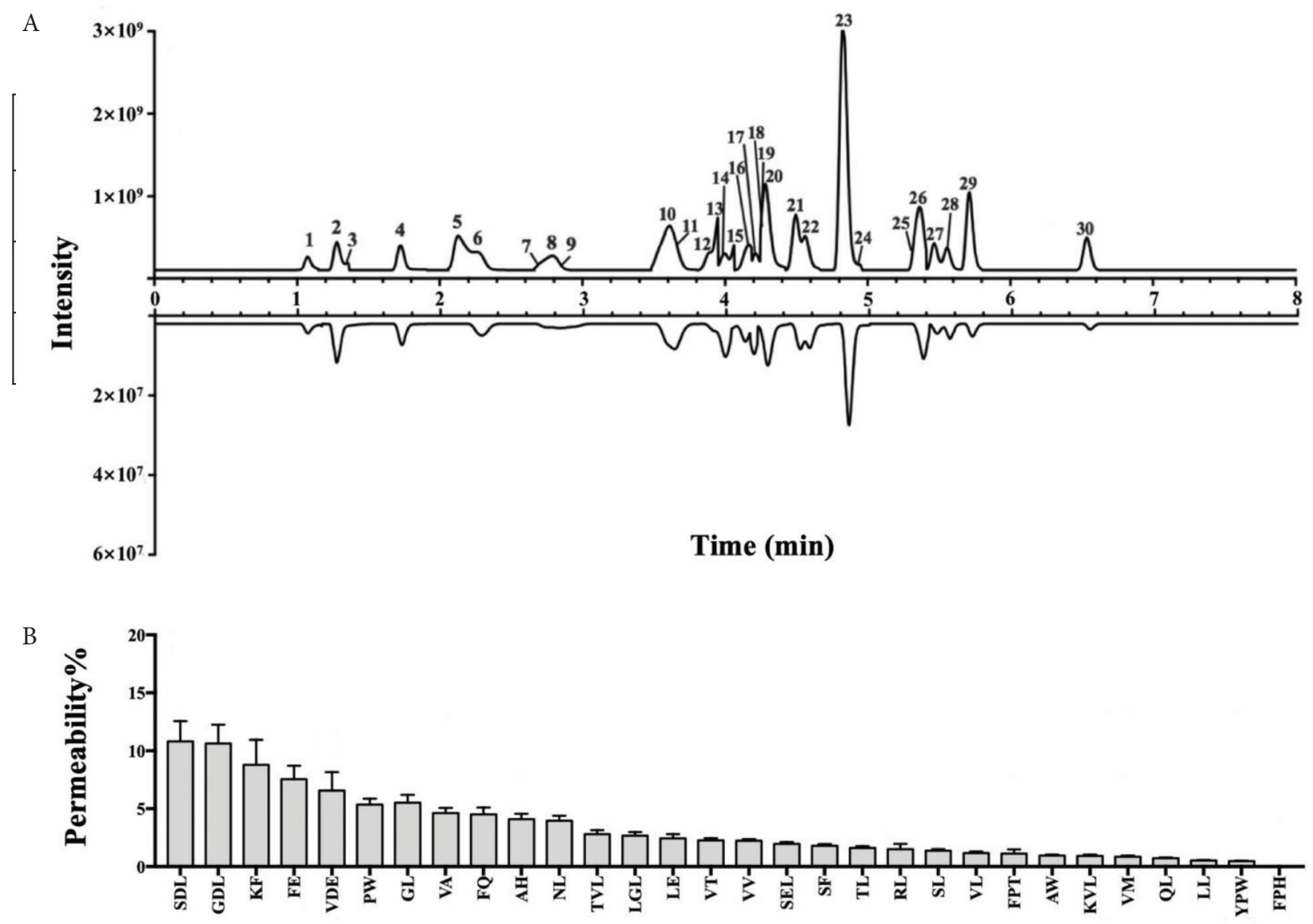

Figure 6 Base peak chromatograms of PBCH-GI on the apical side before transport and the basolateral side after $2 \mathrm{~h}$ of transport (A). Permeability of di-/tripeptides identified from PBCH-GI (B). Numbers 1-30 indicate 30 different di-/tripeptides identified from the hydrolysates. Data are expressed as the mean $\pm \mathrm{SD}, n=3$. PBCH-GI, gastrointestinal-digested pig blood cells hydrolysates. 
Table 1 Identification of major di-/tripeptides from the basolateral permeates

\begin{tabular}{|c|c|c|c|c|c|}
\hline $\begin{array}{c}\text { Peak } \\
\text { no. }\end{array}$ & Sequence & $\begin{array}{c}m / z \\
{[\mathbf{M}+\mathbf{H}]^{+}}\end{array}$ & $\underset{(\mathrm{min})}{\mathbf{R t}}$ & Activities $^{\mathrm{a}}$ & $\begin{array}{c}\text { Parent } \\
\text { protein }^{\mathrm{b}}\end{array}$ \\
\hline 1 & $\mathrm{AH}$ & 227.1137 & 1.15 & $\begin{array}{l}\text { Antioxidative, ACEI, } \\
\text { DPP-IVI }\end{array}$ & $\alpha-; \beta-$ \\
\hline 2 & VA & 189.1233 & 1.26 & DPP-IVI & $\alpha-; \beta-$ \\
\hline 3 & VT & 219.1338 & 1.27 & DPP-IVI & $a-$ \\
\hline 4 & VDE & 361.1714 & 1.74 & ND & $\beta-$ \\
\hline 5 & $\mathrm{RL}$ & 288.2027 & 2.24 & ACEI, DPP-IVI & $a-$ \\
\hline 6 & LE & 261.1444 & 2.34 & ND & $\alpha-$ \\
\hline 7 & VV & 217.1547 & 2.69 & DPP-IVI & $\beta-$ \\
\hline 8 & FQ & 294.1450 & 2.80 & ACEI, DPP-IVI & $\beta-$ \\
\hline 9 & $\mathrm{KF}$ & 294.1808 & 2.95 & ACEI, DPP-IVI & $a-$ \\
\hline 10 & $\mathrm{FE}$ & 295.1286 & 3.47 & ACEI & $\beta-$ \\
\hline 11 & VM & 249.1266 & 3.51 & DPP-IVI & $\beta-$ \\
\hline 12 & SL & 219.1340 & 3.88 & DPP-IVI & $a-$ \\
\hline 13 & NL & 246.1451 & 3.98 & DPP-IVI & $\alpha-; \beta-$ \\
\hline 14 & QL & 260.1599 & 4.00 & DPP-IVI & $\beta-$ \\
\hline 15 & $\mathrm{TL}$ & 233.1492 & 4.09 & DPP-IVI & $a-$ \\
\hline 16 & GL & 189.1235 & 4.18 & DPP-IVI & $\beta-$ \\
\hline 17 & FPH & 400.1975 & 4.19 & ND & $a-$ \\
\hline 18 & KVL & 359.2648 & 4.22 & ND & $\beta-$ \\
\hline 19 & GDL & 304.1498 & 4.28 & Antioxidative & $\beta-$ \\
\hline 20 & SDL & 334.1600 & 4.30 & ND & $\alpha-; \beta-$ \\
\hline 21 & SF & 253.1175 & 4.46 & ACEI, DPP-IVI & $\beta-$ \\
\hline 22 & SEL & 348.1764 & 4.53 & $\mathrm{ND}$ & $\beta-$ \\
\hline 23 & VL & 231.1702 & 4.78 & DPP-IVI & $\alpha-; \beta-$ \\
\hline 24 & $\mathrm{FPT}$ & 364.1865 & 5.13 & ND & $a-$ \\
\hline 25 & AW & 276.1338 & 5.36 & $\begin{array}{l}\text { Antioxidative, ACEI, } \\
\text { DPP-IVI }\end{array}$ & $\alpha-; \beta-$ \\
\hline 26 & TVL & 332.2180 & 5.37 & ND & $\alpha-$ \\
\hline 27 & LGL & 302.2074 & 5.46 & ND & $\beta-$ \\
\hline 28 & PW & 302.1495 & 5.56 & $\begin{array}{l}\text { Antioxidative, } \\
\text { DPP-IVI }\end{array}$ & $\beta$ \\
\hline 29 & LL & 245.1856 & 5.73 & DPP-IVI & $\alpha-; \beta-$ \\
\hline 30 & YPW & 465.2128 & 6.55 & ND & $\beta-$ \\
\hline
\end{tabular}

apeptides activities were searching from the BIOPEP-UWM database and published literatures. ${ }^{b} \alpha$ - means porcine hemoglobin (alpha subunit), $\beta$ - means porcine hemoglobin (beta subunit). ACEI, angiotensin-converting enzyme inhibitory activity; DPP-IVI, dipeptidyl peptidase-IV inhibitory activity; ND indicates that the peptide is not included in the BIOPEP database.

were found to be $0.48-10.80 \%$, and the enterocyte-permeated di-/ tripeptides exerted antioxidant activities. The permeability of four antioxidant di-/tripeptides GDL, AH, PW and AW were 10.62\%, $4.10 \%, 5.35 \%$ and $0.96 \%$, respectively. It is, to the best of our knowledge, the first time to systematically identify di-/tripeptides in the hydrolysates of $\mathrm{PBC}$ and to study the permeability of them. This study clarified that $\mathrm{PBCH}$ contains absorbable and antioxidative di-/tripeptides, exerting high nutritional value, provided us a new technical route to better utilize the $\mathrm{PBC}$ resources, and the $\mathrm{PBCH}$ can be taken as a promising functional food additive. Further studies are needed to study the in vivo bioavailability of di-/tripeptides and clarify the specific structure or amino acid compositions that affect peptides permeability.

\section{CONFLICTS OF INTEREST}

The authors declare they have no conflicts of interest.

\section{AUTHORS' CONTRIBUTION}

$\mathrm{XN}$ and $\mathrm{BD}$ conceived and designed the study. XN, ZZ, ZX, YC, $\mathrm{PL}, \mathrm{LZ}$ and ZX contributed in literature search, experimental data collection and analysis. XN contributed in manuscript writing. BD, JD and CT reviewed and modified the manuscript.

\section{ACKNOWLEDGMENT}

The authors gratefully thank the National Key R\&D Program of China (2018YFD0500600), the National Natural Science Foundation of China (Grant Nos. 31790411), the Natural Science Foundation of Guangdong Province (Grant Nos. 2020A1515010322 and 2017A030310410), the Innovation Team Project in Universities of Guangdong Province (Grant Nos. 2017KCXTD002) and the Guangdong Provincial Promotion Project on Preservation and Utilization of Local Breed of Livestock and Poultry. The studies meet with the approval of the University's Review Board.

\section{REFERENCES}

[1] Lynch SA, Mullen AM, O’Neill EE, García CÁ. Harnessing the potential of blood proteins as functional ingredients: a review of the state of the art in blood processing. Compr Rev Food Sci Food Saf 2017;16:330-44.

[2] Bah CSF, Bekhit AE-DA, Carne A, McConnell MA. Slaughterhouse blood: an emerging source of bioactive compounds. Compr Rev Food Sci Food Saf 2013;12:314-31.

[3] Fu Y, Bak KH, Liu J, De Gobba C, Tøstesen M, Hansen ET, et al. Protein hydrolysates of porcine hemoglobin and blood: Peptide characteristics in relation to taste attributes and formation of volatile compounds. Food Res Int 2019;121:28-38.

[4] Lafarga T, Álvarez C, Hayes M. Bioactive peptides derived from bovine and porcine co-products: a review. J Food Biochem 2017;41:e12418.

[5] Yu Y, Hu J, Miyaguchi Y, Bai X, Du Y, Lin B. Isolation and characterization of angiotensin I-converting enzyme inhibitory peptides derived from porcine hemoglobin. Peptides 2006;27:2950-6.

[6] Bah CSF, Carne A, McConnell MA, Mros S, Bekhit AEL-D. Production of bioactive peptide hydrolysates from deer, sheep, pig and cattle red blood cell fractions using plant and fungal protease preparations. Food Chem 2016;202:458-66.

[7] Zhang Q, Tong X, Qi B, Wang Z, Li Y, Sui X, et al. Changes in antioxidant activity of Alcalase-hydrolyzed soybean hydrolysate under simulated gastrointestinal digestion and transepithelial transport. J Funct Foods 2018;42:298-305.

[8] Zhao GX, Yang XR, Wang YM, Zhao YQ, Chi CF, Wang B. Antioxidant peptides from the protein hydrolysate of Spanish Mackerel (Scomberomorous niphonius) muscle by in vitro gastrointestinal digestion and their in vitro activities. Mar Drugs 2019;17:531.

[9] Liang Q, Chalamaiah M, Ren X, Ma H, Wu J. Identification of new anti-inflammatory peptides from zein hydrolysate after simulated gastrointestinal digestion and transport in Caco-2 cells. J Agric Food Chem 2018;66:1114-20.

[10] Liu C, Ren D, Li J, Fang L, Wang J, Liu J, et al. Cytoprotective effect and purification of novel antioxidant peptides from 
hazelnut (C. heterophylla Fisch) protein hydrolysates. J Funct Foods 2018;42:203-15

[11] Fu Y, Therkildsen M, Aluko RE, Lametsch R. Exploration of collagen recovered from animal by-products as a precursor of bioactive peptides: successes and challenges. Crit Rev Food Sci Nutr 2019;59:2011-27.

[12] Tonolo F, Sandre M, Ferro S, Folda A, Scalcon V, Scutari G, et al. Milk-derived bioactive peptides protect against oxidative stress in a Caco-2 cell model. Food Funct 2018;9:1245-53.

[13] Deng B, Long H, Tang T, Ni X, Chen J, Yang G, et al. Quantitative structure-activity relationship study of antioxidant tripeptides based on model population analysis. Int J Mol Sci 2019;20:995.

[14] Sun Q, Shen H, Luo Y. Antioxidant activity of hydrolysates and peptide fractions derived from porcine hemoglobin. J Food Sci Technol 2011;48:53-60.

[15] Udenigwe CC, Aluko RE. Food protein-derived bioactive peptides: production, processing, and potential health benefits. J Food Sci 2012;77:R11-24.

[16] Miner-Williams WM, Stevens BR, Moughan PJ. Are intact peptides absorbed from the healthy gut in the adult human? Nutr Res Rev 2014;27:308-29.

[17] Daniel H. Molecular and integrative physiology of intestinal peptide transport. Annu Rev Physiol 2004;66:361-84.

[18] Nielsen PM, Petersen D, Dambmann C. Improved method for determining food protein degree of hydrolysis. J Food Sci 2001;66:642-6.

[19] Cinq-Mars CD, Hu C, Kitts DD, Li-Chan EC. Investigations into inhibitor type and mode, simulated gastrointestinal digestion, and cell transport of the angiotensin I-converting enzymeinhibitory peptides in pacific hake (Merluccius productus) fillet hydrolysate. J Agric Food Chem 2008;56:410-9.

[20] Brand-Williams W, Cuvelier ME, Berset C. Use of a free radical method to evaluate antioxidant activity. Leb Wiss Technol 1995;28:25-30.

[21] Zhai Z, Ni X, Jin C, Ren W, Li J, Deng J, et al. Cecropin A modulates tight junction-related protein expression and enhances the barrier function of porcine intestinal epithelial cells by suppressing the MEK/ERK pathway. Int J Mol Sci 2018;19:1941.

[22] Wang L, Ding L, Yu Z, Zhang T, Ma S, Liu J. Intracellular ROS scavenging and antioxidant enzyme regulating capacities of corn gluten meal-derived antioxidant peptides in HepG2 cells. Food Res Int 2016;90:33-41.
[23] Tang Y, Li R, Lin G, Li L. PEP search in MyCompoundID: detection and identification of dipeptides and tripeptides using dimethyl labeling and hydrophilic interaction liquid chromatography tandem mass spectrometry. Anal Chem 2014;86:3568-74.

[24] Deng B, Ni X, Zhai Z, Tang T, Tan C, Yan Y, et al. New quantitative structure-activity relationship model for angiotensin-converting enzyme inhibitory dipeptides based on integrated descriptors. J Agric Food Chem 2017;65:9774-81.

[25] Minkiewicz P, Dziuba J, Iwaniak A, Dziuba M, Darewicz M. BIOPEP database and other programs for processing bioactive peptide sequences. J AOAC Int 2008;91:965-80.

[26] Pluskal T, Castillo S, Villar-Briones A, Orešič M. MZmine 2: modular framework for processing,visualizing, and analyzing mass spectrometry-based molecular profile data. BMC Bioinformatics 2010;11:395.

[27] Xin Z, Ma S, Ren D, Liu W, Han B, Zhang Y, et al. UPLCOrbitrap-MS/MS combined with chemometrics establishes variations in chemical components in green tea from Yunnan and Hunan origins. Food Chem 2018;266:534-44.

[28] Shahidi F, Zhong Y. Measurement of antioxidant activity. J Funct Foods 2015;18:757-81.

[29] Chang CY, Wu KC, Chiang SH. Antioxidant properties and protein compositions of porcine haemoglobin hydrolysates. Food Chem 2007;100:1537-43.

[30] Borawska J, Darewicz M, Vegarud GE, Minkiewicz P. Antioxidant properties of carp (Cyprinus carpio L.) protein ex vivo and in vitro hydrolysates. Food Chem 2016;194:770-9.

[31] Ao J, Li B. Stability and antioxidative activities of casein peptide fractions during simulated gastrointestinal digestion in vitro: charge properties of peptides affect digestive stability. Food Res Int 2013;52:334-41.

[32] Gu Y, Wu J. LC-MS/MS coupled with QSAR modeling in characterising of angiotensin I-converting enzyme inhibitory peptides from soybean proteins. Food Chem 2013;141:2682-90.

[33] Rohm F, Daniel H, Spanier B. Transport versus hydrolysis: reassessing intestinal assimilation of di- and tripeptides by LC-MS/ MS analysis. Mol Nutr Food Res 2019;63:e1900263.

[34] Sangsawad P, Roytrakul S, Choowongkomon K, Kitts DD, Chen XM, Meng G, et al. Transepithelial transport across Caco-2 cell monolayers of angiotensin converting enzyme (ACE) inhibitory peptides derived from simulated in vitro gastrointestinal digestion of cooked chicken muscles. Food Chem 2018;251:77-85.

[35] Wang B, Li B. Effect of molecular weight on the transepithelial transport and peptidase degradation of casein-derived peptides by using Caco-2 cell model. Food Chem 2017;218:1-8. 


\section{SUPPLEMENTARY MATERIALS}

Tables listing the results for optimizing the extraction conditions (Tables S1-S3) and the information of all identified di-/tripeptides from hydrolysates (Table S4).

Table S1 The levels of the independent variables in Box-Behnken design

\begin{tabular}{lcrcr}
\hline & & \multicolumn{3}{c}{ Coded levels } \\
\cline { 3 - 5 } Variables & Code & $\mathbf{- 1}$ & $\mathbf{0}$ & $\boldsymbol{+ 1}$ \\
\hline Time $(\mathrm{h})$ & $\mathrm{A}$ & 20 & 25 & 30 \\
$\mathrm{pH}$ & $\mathrm{B}$ & 8 & 9 & 10 \\
Temperature $\left({ }^{\circ} \mathrm{C}\right)$ & $\mathrm{C}$ & 30 & 40 & 50 \\
E/S $($ w/w) & $\mathrm{D}$ & 1 & 2.5 & 4 \\
\hline
\end{tabular}

Table S2 Experimental design and measured values for the response variable

\begin{tabular}{|c|c|c|c|c|c|c|}
\hline \multirow{2}{*}{ Run } & \multirow{2}{*}{$\mathbf{A}$} & \multirow{2}{*}{ B } & \multirow{2}{*}{$\mathrm{C}$} & \multirow{2}{*}{ D } & \multicolumn{2}{|c|}{$\mathrm{DH}(\%)^{1}$} \\
\hline & & & & & Experimental & Predicted \\
\hline 1 & 25 & 9 & 40 & 2.5 & 45.79 & 46.49 \\
\hline 2 & 25 & 8 & 50 & 2.5 & 34.93 & 36.34 \\
\hline 3 & 30 & 9 & 40 & 1 & 44.90 & 43.38 \\
\hline 4 & 25 & 8 & 40 & 4 & 44.69 & 43.91 \\
\hline 5 & 25 & 9 & 40 & 2.5 & 47.32 & 46.49 \\
\hline 6 & 30 & 10 & 40 & 2.5 & 49.13 & 49.74 \\
\hline 7 & 20 & 9 & 30 & 2.5 & 30.00 & 29.29 \\
\hline 8 & 30 & 8 & 40 & 2.5 & 47.35 & 47.33 \\
\hline 9 & 25 & 10 & 50 & 2.5 & 36.88 & 36.61 \\
\hline 10 & 25 & 9 & 30 & 4 & 35.95 & 36.80 \\
\hline 11 & 30 & 9 & 50 & 2.5 & 38.91 & 39.51 \\
\hline 12 & 25 & 10 & 40 & 1 & 40.24 & 40.91 \\
\hline 13 & 30 & 9 & 30 & 2.5 & 38.18 & 39.21 \\
\hline 14 & 25 & 8 & 30 & 2.5 & 33.18 & 32.79 \\
\hline 15 & 25 & 10 & 30 & 2.5 & 39.17 & 37.11 \\
\hline 16 & 20 & 8 & 40 & 2.5 & 38.59 & 38.75 \\
\hline 17 & 25 & 9 & 40 & 2.5 & 46.65 & 46.49 \\
\hline 18 & 20 & 9 & 40 & 1 & 32.86 & 32.90 \\
\hline 19 & 20 & 9 & 50 & 2.5 & 33.18 & 32.04 \\
\hline 20 & 30 & 9 & 40 & 4 & 47.58 & 46.89 \\
\hline 21 & 25 & 9 & 40 & 2.5 & 46.52 & 46.49 \\
\hline 22 & 25 & 9 & 40 & 2.5 & 46.14 & 46.49 \\
\hline 23 & 25 & 8 & 40 & 1 & 37.13 & 36.76 \\
\hline 24 & 25 & 9 & 50 & 4 & 33.63 & 33.12 \\
\hline 25 & 20 & 10 & 40 & 2.5 & 40.13 & 40.92 \\
\hline 26 & 20 & 9 & 40 & 4 & 39.09 & 39.96 \\
\hline 27 & 25 & 10 & 40 & 4 & 44.08 & 44.34 \\
\hline 28 & 25 & 9 & 30 & 1 & 25.03 & 26.30 \\
\hline 29 & 25 & 9 & 50 & 1 & 33.12 & 33.03 \\
\hline
\end{tabular}

${ }^{1} \mathrm{DH}(\%)$ represents the average degree of hydrolysis of triplicate experiments. A, B, $\mathrm{C}$ and $\mathrm{D}$ are the coded variables, indicating incubation period, $\mathrm{pH}$, temperature and enzyme-to-substrate ratio (E/S, w/w), respectively.
Table S3 ANOVA for response surface quadratic polynomial mode

\begin{tabular}{|c|c|c|c|c|c|}
\hline Variables & $\begin{array}{l}\text { Sum of } \\
\text { squares }\end{array}$ & df & $\begin{array}{c}\text { Mean } \\
\text { square }\end{array}$ & $F$-value & $p$-value \\
\hline Model & 1070.74 & 14 & 76.48 & 54.92 & $<0.0001$ \\
\hline A & 227.12 & 1 & 227.12 & 163.08 & $<0.0001$ \\
\hline B & 15.73 & 1 & 15.73 & 11.30 & 0.0047 \\
\hline $\mathrm{C}$ & 6.97 & 1 & 6.97 & 5.01 & 0.0420 \\
\hline $\mathrm{D}$ & 83.95 & 1 & 83.95 & 60.28 & $<0.0001$ \\
\hline $\mathrm{AB}$ & 0.01 & 1 & 0.01 & 0.01 & 0.9210 \\
\hline $\mathrm{AC}$ & 1.50 & 1 & 1.50 & 1.08 & 0.3170 \\
\hline $\mathrm{AD}$ & 3.16 & 1 & 3.16 & 2.27 & 0.1540 \\
\hline $\mathrm{BC}$ & 4.09 & 1 & 4.09 & 2.93 & 0.1090 \\
\hline $\mathrm{BD}$ & 3.46 & 1 & 3.46 & 2.48 & 0.1370 \\
\hline $\mathrm{CD}$ & 27.12 & 1 & 27.12 & 19.47 & 0.0006 \\
\hline $\mathrm{A}^{2}$ & 14.64 & 1 & 14.64 & 10.51 & 0.0059 \\
\hline $\mathrm{B}^{2}$ & 4.19 & 1 & 4.19 & 3.01 & 0.1050 \\
\hline $\mathrm{C}^{2}$ & 644.84 & 1 & 644.84 & 463.03 & $<0.0001$ \\
\hline $\mathrm{D}^{2}$ & 114.59 & 1 & 114.59 & 82.28 & $<0.0001$ \\
\hline Residual & 19.50 & 14 & 1.39 & & \\
\hline Lack of fit & 18.17 & 10 & 1.82 & 5.47 & 0.0580 \\
\hline Pure error & 1.33 & 4 & 0.33 & & \\
\hline $\begin{array}{l}\text { Corrected } \\
\text { total sum } \\
\text { of squares }\end{array}$ & 1090.24 & 28 & & & \\
\hline$R^{2}$ & 0.98 & & & & \\
\hline Adjusted $R^{2}$ & 0.96 & & & & \\
\hline Predicted $R^{2}$ & 0.90 & & & & \\
\hline CV (\%) & 2.97 & & & & \\
\hline
\end{tabular}

$p<0.001$ means extremely significant; $p<0.01$ means very significant; $p<0.05$ means significant. df refers to degree of freedom. A, B, C and D are the coded variables, refer to incubation period, $\mathrm{pH}$, temperature and enzyme-to-substrate ratio (E/S, w/w), respectively.

Polynomial equation:

$$
\begin{aligned}
\mathrm{DH}(\%)= & 46.49+4.35 \mathrm{~A}+1.15 \mathrm{~B}+0.76 \mathrm{C}+2.64 \mathrm{D}+0.06 \mathrm{AB} \\
& -0.61 \mathrm{AC}-0.89 \mathrm{AD}-1.01 \mathrm{BC}-0.93 \mathrm{BD}-2.60 \mathrm{CD} \\
& -1.50 \mathrm{~A}^{2}-0.80 \mathrm{~B}^{2}-9.97 \mathrm{C}^{2}-4.20 \mathrm{D}^{2}
\end{aligned}
$$


Table S4 Qualitative and quantitative analysis results of di-/tripeptides in hydrolysates ${ }^{1}$

\begin{tabular}{|c|c|c|c|c|c|c|c|c|c|}
\hline \multirow{2}{*}{$\begin{array}{l}\text { Peak } \\
\text { no. }\end{array}$} & \multirow{2}{*}{ Sequence } & \multirow{2}{*}{$\begin{array}{c}\text { Rt } \\
(\min )\end{array}$} & \multirow{2}{*}{$\begin{array}{c}m / z \\
{[\mathbf{M}+\mathbf{H}]^{+}}\end{array}$} & \multirow{2}{*}{$\begin{array}{l}\text { Error } \\
(\text { ppm })\end{array}$} & \multirow{2}{*}{$\begin{array}{l}\text { Molecular } \\
\text { formula }\end{array}$} & \multirow{2}{*}{ MS/MS fragments } & \multirow{2}{*}{$\begin{array}{l}\text { Parent } \\
\text { protein }\end{array}$} & \multicolumn{2}{|c|}{ Concentration $(\mu \mathrm{g} / \mathrm{mL})$} \\
\hline & & & & & & & & РBCH & PBCH-GI \\
\hline 1 & $\mathrm{AH}$ & 1.15 & 227.1137 & -0.955 & $\mathrm{C}_{9} \mathrm{H}_{15} \mathrm{O}_{3} \mathrm{~N}_{4}$ & $\begin{array}{l}156.0766,110.0715,227.1136,209.1031 \\
\quad 226.0799\end{array}$ & $\alpha-; \beta-$ & $56.72 \pm 12.56$ & $59.6 \pm 4.98$ \\
\hline 2 & VA & 1.26 & 189.1233 & -0.289 & $\mathrm{C}_{8} \mathrm{H}_{17} \mathrm{O}_{3} \mathrm{~N}_{2}$ & $\begin{array}{l}\text { 72.0814, 112.0759, 70.0658, 189.1231, } \\
55.0550\end{array}$ & $\alpha-; \beta-$ & $102.98 \pm 56.47$ & $100.89 \pm 7.36$ \\
\hline 3 & VT & 1.27 & 219.1338 & -0.792 & $\mathrm{C}_{9} \mathrm{H}_{19} \mathrm{O}_{4} \mathrm{~N}_{2}$ & $\begin{array}{l}72.0814,86.0969,120.0656,55.0550 \\
\quad 148.0606\end{array}$ & $\alpha-$ & $36.46 \pm 10.97$ & $35.71 \pm 2.68$ \\
\hline 4 & VDE & 1.74 & 361.1714 & -1.067 & $\mathrm{C}_{14} \mathrm{H}_{25} \mathrm{O}_{7} \mathrm{~N}_{4}$ & $\begin{array}{l}\text { 72.0814, 148.0603, 361.1714, 130.0499, } \\
\quad 205.0817\end{array}$ & $\beta-$ & $102.70 \pm 32.87$ & $92.26 \pm 8.88$ \\
\hline 5 & $\mathrm{RL}$ & 2.24 & 288.2027 & -0.993 & $\mathrm{C}_{12} \mathrm{H}_{26} \mathrm{O}_{3} \mathrm{~N}_{5}$ & $\begin{array}{l}\text { 70.0658, 288.2027, 175.1188, 60.0564, } \\
\quad 289.2058\end{array}$ & $\alpha-$ & $158.13 \pm 39.65$ & $254.71 \pm 17.06$ \\
\hline 6 & $\mathrm{LE}$ & 2.34 & 261.1444 & -0.233 & $\mathrm{C}_{11} \mathrm{H}_{21} \mathrm{O}_{5} \mathrm{~N}_{2}$ & $\begin{array}{l}86.0969,148.0603,84.0813,261.1444 \\
\quad 60.0452\end{array}$ & $\alpha-$ & $127.05 \pm 44.98$ & $81.06 \pm 8.95$ \\
\hline 7 & VV & 2.69 & 217.1547 & -0.088 & $\mathrm{C}_{10} \mathrm{H}_{21} \mathrm{O}_{3} \mathrm{~N}_{2}$ & $\begin{array}{l}\text { 72.0814, 175.1187, 200.0708, 70.0657, } \\
\quad 91.0547\end{array}$ & $\beta-$ & $74.12 \pm 23.56$ & $47.65 \pm 3.47$ \\
\hline 8 & FQ & 2.80 & 294.1450 & 0.433 & $\mathrm{C}_{14} \mathrm{H}_{20} \mathrm{O}_{4} \mathrm{~N}_{3}$ & $\begin{array}{l}120.0809,147.0763,130.0499,84.0813 \\
294.1446\end{array}$ & $\beta-$ & $51.42 \pm 15.81$ & $67.18 \pm 4.95$ \\
\hline 9 & $\mathrm{KF}$ & 2.95 & 294.1808 & -1.353 & $\mathrm{C}_{15} \mathrm{H}_{24} \mathrm{O}_{3} \mathrm{~N}_{3}$ & $\begin{array}{l}84.0813,294.1808,129.1023,120.0810 \\
\quad 277.1538\end{array}$ & $\alpha-$ & $56.44 \pm 22.59$ & $57.55 \pm 4.06$ \\
\hline 10 & $\mathrm{FE}$ & 3.47 & 295.1286 & -0.739 & $\mathrm{C}_{14} \mathrm{H}_{19} \mathrm{O}_{5} \mathrm{~N}_{2}$ & $\begin{array}{l}120.0809,295.1286,121.0843,148.0603 \\
84.0813\end{array}$ & $\beta-$ & $250.46 \pm 83.44$ & $223.53 \pm 17.49$ \\
\hline 11 & VM & 3.51 & 249.1266 & -0.44 & $\mathrm{C}_{10} \mathrm{H}_{21} \mathrm{O}_{3} \mathrm{~N}_{2} \mathrm{~S}$ & $\begin{array}{l}\text { 72.0814, 150.0582, 55.0550, 249.1266, } \\
\quad 104.0531\end{array}$ & $\beta-$ & $128.42 \pm 43.81$ & $137.6 \pm 9.59$ \\
\hline 12 & SL & 3.88 & 219.1340 & 0.121 & $\mathrm{C}_{9} \mathrm{H}_{19} \mathrm{O}_{4} \mathrm{~N}_{2}$ & $\begin{array}{l}74.0607,132.1019,86.0969,233.1492 \\
56.0502\end{array}$ & $\alpha-$ & $69.39 \pm 23.30$ & $75.28 \pm 7.10$ \\
\hline 13 & NL & 3.98 & 246.1451 & 0.883 & $\mathrm{C}_{10} \mathrm{H}_{20} \mathrm{O}_{4} \mathrm{~N}_{3}$ & $\begin{array}{l}86.0969,212.0916,166.0863,132.1017 \\
\quad 87.0558\end{array}$ & $\alpha-; \beta-$ & $143.11 \pm 41.09$ & $222.93 \pm 14.59$ \\
\hline 14 & QL & 4.00 & 260.1599 & -1.356 & $\mathrm{C}_{11} \mathrm{H}_{22} \mathrm{O}_{4} \mathrm{~N}_{3}$ & $\begin{array}{l}101.0713,86.0969,132.1019 \\
129.0659,84.0449\end{array}$ & $\beta-$ & $57.05 \pm 18.67$ & $81.29 \pm 5.65$ \\
\hline 15 & $\mathrm{TL}$ & 4.09 & 233.1492 & -1.517 & $\mathrm{C}_{10} \mathrm{H}_{21} \mathrm{O}_{4} \mathrm{~N}_{2}$ & $\begin{array}{l}\text { 74.0607, 132.1019, 86.0969, 233.1492, } \\
56.0502\end{array}$ & $a^{-}$ & $102.41 \pm 28.02$ & $155.21 \pm 11.77$ \\
\hline 16 & GL & 4.18 & 189.1235 & 0.535 & $\mathrm{C}_{8} \mathrm{H}_{17} \mathrm{O}_{3} \mathrm{~N}_{2}$ & $\begin{array}{l}86.0969,132.1019,143.1178,87.1001 \\
\quad 72.0814\end{array}$ & $\beta-$ & $178.11 \pm 49.38$ & $157.06 \pm 11.63$ \\
\hline 17 & FPH & 4.19 & 400.1975 & -1.051 & $\mathrm{C}_{20} \mathrm{H}_{26} \mathrm{O}_{4} \mathrm{~N}_{5}$ & $\begin{array}{l}156.0767,110.0715,70.0658,400.1975 \\
\quad 120.0810\end{array}$ & $\alpha-$ & $147.21 \pm 35.63$ & $109.55 \pm 8.30$ \\
\hline 18 & KVL & 4.22 & 359.2648 & -1.342 & $\mathrm{C}_{17} \mathrm{H}_{35} \mathrm{O}_{4} \mathrm{~N}_{4}$ & $\begin{array}{l}84.0813,129.1022,359.2648,72.0814 \\
\quad 86.0969\end{array}$ & $\beta-$ & $46.33 \pm 12.42$ & $68.25 \pm 4.76$ \\
\hline 19 & GDL & 4.28 & 304.1498 & -0.327 & $\mathrm{C}_{12} \mathrm{H}_{22} \mathrm{O}_{6} \mathrm{~N}_{3}$ & $\begin{array}{l}86.0969,127.0503,132.1019,173.0557 \\
88.0398\end{array}$ & $\beta-$ & $194.19 \pm 50.70$ & $191.11 \pm 13.14$ \\
\hline 20 & SDL & 4.30 & 334.1600 & 1.485 & $\mathrm{C}_{11} \mathrm{H}_{22} \mathrm{O}_{6} \mathrm{~N}_{6}$ & $\begin{array}{l}86.0969,157.0608,203.0660,60.0451 \\
\quad 132.1019\end{array}$ & $\alpha-; \beta-$ & $187.3 \pm 50.48$ & $198.3 \pm 14.63$ \\
\hline 21 & SF & 4.46 & 253.1175 & -3.135 & $\mathrm{C}_{12} \mathrm{H}_{17} \mathrm{O}_{4} \mathrm{~N}_{2}$ & $\begin{array}{l}120.0809,166.0861,60.0451,207.1123 \\
253.1161\end{array}$ & $\beta-$ & $124.37 \pm 32.93$ & $198.84 \pm 15.69$ \\
\hline 22 & SEL & 4.53 & 348.1764 & -0.392 & $\mathrm{C}_{14} \mathrm{H}_{26} \mathrm{O}_{7} \mathrm{~N}_{3}$ & $\begin{array}{l}217.0817,189.0869,126.0550,60.0452 \\
\quad 154.0499\end{array}$ & $\beta-$ & $114.05 \pm 33.41$ & $118.37 \pm 8.64$ \\
\hline 23 & VL & 4.78 & 231.1702 & -0.602 & $\mathrm{C}_{11} \mathrm{H}_{23} \mathrm{O}_{3} \mathrm{~N}_{2}$ & $\begin{array}{l}\text { 72.0814, 55.0550, 132.1019, 86.0969, } \\
\quad 231.1702\end{array}$ & $\alpha-; \beta-$ & $698.08 \pm 191.83$ & $827.19 \pm 411.86$ \\
\hline 24 & FPT & 5.13 & 364.1865 & -0.487 & $\mathrm{C}_{18} \mathrm{H}_{26} \mathrm{O}_{5} \mathrm{~N}_{3}$ & $\begin{array}{l}70.0658,217.1174,120.0809,364.1865 \\
245.1283\end{array}$ & $\alpha-$ & $80.81 \pm 51.26$ & $48.13 \pm 3.31$ \\
\hline 25 & AW & 5.36 & 276.1338 & 0.152 & $\mathrm{C}_{14} \mathrm{H}_{18} \mathrm{O}_{3} \mathrm{~N}_{3}$ & $\begin{array}{l}188.0704,205.0970,146.0599,276.1340 \\
\quad 189.0740\end{array}$ & $\alpha-; \beta-$ & $114.68 \pm 27.56$ & $141.77 \pm 9.27$ \\
\hline 26 & TVL & 5.37 & 332.2180 & -0.113 & $\mathrm{C}_{15} \mathrm{H}_{30} \mathrm{O}_{5} \mathrm{~N}_{3}$ & $\begin{array}{l}\text { 72.0814, 112.0759, 70.0658, 189.1231, } \\
55.0550\end{array}$ & $\alpha-$ & $73.79 \pm 18.04$ & $239.78 \pm 16.71$ \\
\hline 27 & LGL & 5.46 & 302.2074 & -0.208 & $\mathrm{C}_{14} \mathrm{H}_{28} \mathrm{O}_{4} \mathrm{~N}_{3}$ & $\begin{array}{l}\text { 72.0814, 143.1178, 171.1126, 86.0969, } \\
132.1020\end{array}$ & $\beta-$ & $62.88 \pm 18.09$ & $90.44 \pm 6.79$ \\
\hline 28 & PW & 5.56 & 302.1495 & -1.45 & $\mathrm{C}_{16} \mathrm{H}_{20} \mathrm{O}_{3} \mathrm{~N}_{3}$ & $\begin{array}{l}\text { 70.0658, 72.0814, 143.1178, 171.1126, } \\
\quad 302.1495\end{array}$ & $\beta-$ & $96.85 \pm 27.38$ & $72.11 \pm 5.15$ \\
\hline 29 & $\mathrm{LL}$ & 5.73 & 245.1856 & -0.16 & $\mathrm{C}_{12} \mathrm{H}_{25} \mathrm{O}_{3} \mathrm{~N}_{2}$ & $\begin{array}{l}86.0969,245.1856,87.1001,132.1019 \\
\quad 199.1803\end{array}$ & $\alpha-; \beta-$ & $86.09 \pm 28.73$ & $280.66 \pm 20.84$ \\
\hline 30 & YPW & 6.55 & 465.2128 & -1.024 & $\mathrm{C}_{25} \mathrm{H}_{29} \mathrm{O}_{5} \mathrm{~N}_{4}$ & $\begin{array}{l}70.0658,465.2130,302.1496,136.0756 \\
\quad 188.0704\end{array}$ & $\beta-$ & $165.19 \pm 74.38$ & $112.6 \pm 10.45$ \\
\hline 31 & AA & 1.19 & 161.0920 & -0.241 & $\mathrm{C}_{6} \mathrm{H}_{13} \mathrm{O}_{3} \mathrm{~N}_{2}$ & $\begin{array}{l}90.0554,161.0920,115.0869,103.0392 \\
60.0814\end{array}$ & $\alpha-; \beta-$ & $30.73 \pm 8.33$ & $31.27 \pm 2.07$ \\
\hline
\end{tabular}


Table S4 Qualitative and quantitative analysis results of di-/tripeptides in hydrolysates ${ }^{1}$ - Continued

\begin{tabular}{|c|c|c|c|c|c|c|c|c|c|}
\hline \multirow{2}{*}{$\begin{array}{l}\text { Peak } \\
\text { no. }\end{array}$} & \multirow{2}{*}{ Sequence } & \multirow{2}{*}{$\begin{array}{c}\text { Rt } \\
(\min )\end{array}$} & \multirow{2}{*}{$\begin{array}{c}m / z \\
{[\mathbf{M}+\mathbf{H}]^{+}}\end{array}$} & \multirow{2}{*}{$\begin{array}{l}\text { Error } \\
(\text { ppm })\end{array}$} & \multirow{2}{*}{$\begin{array}{l}\text { Molecular } \\
\text { formula }\end{array}$} & \multirow{2}{*}{ MS/MS fragments } & \multirow{2}{*}{$\begin{array}{l}\text { Parent } \\
\text { protein }\end{array}$} & \multicolumn{2}{|c|}{ Concentration $(\mu \mathrm{g} / \mathrm{mL})$} \\
\hline & & & & & & & & PBCH & PBCH-GI \\
\hline 32 & AAW & 5.55 & 347.1720 & 1.695 & $\mathrm{C}_{17} \mathrm{H}_{23} \mathrm{O}_{4} \mathrm{~N}_{4}$ & $\begin{array}{l}188.0704,205.0970,146.0600,115.0868 \\
\quad 159.0916\end{array}$ & $\alpha-$ & $3.36 \pm 0.89$ & $16.34 \pm 1.11$ \\
\hline 33 & $\mathrm{AE}$ & 1.23 & 219.0979 & 0.42 & $\mathrm{C}_{8} \mathrm{H}_{15} \mathrm{O}_{5} \mathrm{~N}_{2}$ & $\begin{array}{l}148.0604,84.0449,200.1028,130.0498 \\
\quad 201.0874\end{array}$ & $\alpha-; \beta-$ & $13.47 \pm 3.16$ & $10.17 \pm 0.80$ \\
\hline 34 & $\mathrm{AEE}$ & 1.33 & 348.1396 & -1.583 & $\mathrm{C}_{13} \mathrm{H}_{22} \mathrm{O}_{8} \mathrm{~N}_{3}$ & $\begin{array}{l}102.0553,173.0920,201.0869,84.0449 \\
\quad 148.0603\end{array}$ & $\beta-$ & $34.02 \pm 8.15$ & $29.25 \pm 1.92$ \\
\hline 35 & $\mathrm{AF}$ & 4.71 & 237.1231 & -1.429 & $\mathrm{C}_{12} \mathrm{H}_{17} \mathrm{O}_{3} \mathrm{~N}_{2}$ & $\begin{array}{l}120.0810,166.0863,121.0843,167.0897 \\
237.1228\end{array}$ & $\beta-$ & $12.45 \pm 4.10$ & $19.25 \pm 1.32$ \\
\hline 36 & $\mathrm{AK}$ & 1.07 & 218.1498 & -0.633 & $\mathrm{C}_{9} \mathrm{H}_{20} \mathrm{O}_{3} \mathrm{~N}_{3}$ & $\begin{array}{l}84.0813,129.1022,218.1498,147.1127 \\
\quad 130.0863\end{array}$ & $\beta-$ & $11.34 \pm 2.50$ & $11.76 \pm 1.08$ \\
\hline 37 & AKL & 2.32 & 331.2339 & -0.278 & $\mathrm{C}_{15} \mathrm{H}_{31} \mathrm{O}_{4} \mathrm{~N}_{4}$ & $\begin{array}{l}84.0813,129.1023,331.2339,86.0969 \\
\quad 101.1075\end{array}$ & $\beta-$ & $3.36 \pm 1.13$ & $8.04 \pm 0.63$ \\
\hline 38 & $\mathrm{AL}$ & 4.04 & 203.1395 & -0.29 & $\mathrm{C}_{9} \mathrm{H}_{19} \mathrm{O}_{3} \mathrm{~N}_{2}$ & $\begin{array}{l}132.1019,86.0969,157.1335,203.1390 \\
133.1055\end{array}$ & $\alpha-; \beta-$ & $3.13 \pm 1.36$ & $5.03 \pm 0.37$ \\
\hline 39 & ALE & 3.48 & 332.1813 & -0.458 & $\mathrm{C}_{14} \mathrm{H}_{26} \mathrm{O}_{6} \mathrm{~N}_{3}$ & $\begin{array}{l}86.0969,157.1334,185.1283,148.0603 \\
\quad 129.1023\end{array}$ & $\alpha-$ & $8.15 \pm 2.72$ & $15.06 \pm 1.20$ \\
\hline 40 & ANV & 2.46 & 303.1663 & -0.021 & $\mathrm{C}_{12} \mathrm{H}_{23} \mathrm{O}_{5} \mathrm{~N}_{4}$ & $\begin{array}{l}186.0872,72.0814,141.0658,240.1340 \\
\quad 152.0706\end{array}$ & $\alpha-$ & $2.00 \pm 0.74$ & $2.76 \pm 0.24$ \\
\hline 41 & $\mathrm{AR}$ & 1.10 & 246.1559 & -0.634 & $\mathrm{C}_{9} \mathrm{H}_{20} \mathrm{O}_{3} \mathrm{~N}_{5}$ & $\begin{array}{l}246.1559,175.1189,110.0716,70.0658 \\
84.0813\end{array}$ & $\beta-$ & $1.90 \pm 0.47$ & $8.46 \pm 0.73$ \\
\hline 42 & AVM & 4.51 & 320.1634 & -0.105 & $\mathrm{C}_{13} \mathrm{H}_{26} \mathrm{O}_{4} \mathrm{~N}_{3} \mathrm{~S}$ & $\begin{array}{l}72.0814,143.1178,171.1126,150.0582 \\
\quad 104.0532\end{array}$ & $\beta-$ & $8.61 \pm 2.48$ & $29.83 \pm 2.16$ \\
\hline 43 & DAL & 4.67 & 318.1656 & -0.132 & $\mathrm{C}_{13} \mathrm{H}_{24} \mathrm{O}_{6} \mathrm{~N}_{3}$ & $\begin{array}{l}159.0765,86.097,187.0714,132.102 \\
88.0398\end{array}$ & $\alpha-$ & $10.96 \pm 3.44$ & $21.16 \pm 1.56$ \\
\hline 44 & DKF & 3.19 & 409.2077 & -1.493 & $\mathrm{C}_{19} \mathrm{H}_{29} \mathrm{O}_{6} \mathrm{~N}_{4}$ & $\begin{array}{l}120.0809,409.2076,84.0813,130.0862 \\
\quad 147.1126\end{array}$ & $\alpha-$ & $17.47 \pm 5.88$ & $18.89 \pm 1.35$ \\
\hline 45 & $\mathrm{DL}$ & 4.24 & 247.1287 & 1.343 & $\mathrm{C}_{10} \mathrm{H}_{19} \mathrm{O}_{5} \mathrm{~N}_{2}$ & $\begin{array}{l}86.0969,88.0398,132.102,201.1234 \\
\quad 166.0862\end{array}$ & $\alpha-; \beta-$ & $13.73 \pm 3.74$ & $15.09 \pm 1.11$ \\
\hline 46 & DLH & 1.79 & 384.1868 & -1.718 & $\mathrm{C}_{16} \mathrm{H}_{26} \mathrm{O}_{6} \mathrm{~N}_{5}$ & $\begin{array}{l}110.0715,156.0767,384.1871,86.0969 \\
\quad 201.1234\end{array}$ & $\alpha-$ & $8.45 \pm 2.66$ & $8.74 \pm 0.68$ \\
\hline 47 & DPV & 3.54 & 330.1656 & -0.945 & $\mathrm{C}_{14} \mathrm{H}_{24} \mathrm{O}_{6} \mathrm{~N}_{3}$ & $\begin{array}{l}\text { 70.0658, 330.1656, 185.0921, 215.1391, } \\
\quad 84.0814\end{array}$ & $\alpha-$ & $17.69 \pm 6.03$ & $11.91 \pm 0.84$ \\
\hline 48 & DQL & 4.44 & 375.1872 & -0.708 & $\mathrm{C}_{15} \mathrm{H}_{27} \mathrm{O}_{7} \mathrm{~N}_{4}$ & $\begin{array}{l}86.0969,244.0927,88.0398,375.1872 \\
\quad 132.1019\end{array}$ & $\beta-$ & $4.51 \pm 1.24$ & $3.50 \pm 0.23$ \\
\hline 49 & EAL & 4.72 & 332.1815 & -0.277 & $\mathrm{C}_{14} \mathrm{H}_{26} \mathrm{O}_{6} \mathrm{~N}_{3}$ & $\begin{array}{l}86.0969,132.1019,84.0450,155.0814 \\
\quad 203.1389\end{array}$ & $\alpha-; \beta-$ & $8.09 \pm 2.53$ & $9.54 \pm 0.78$ \\
\hline 50 & EK & 1.12 & 276.1549 & -1.801 & $\mathrm{C}_{11} \mathrm{H}_{22} \mathrm{O}_{5} \mathrm{~N}_{3}$ & $\begin{array}{l}84.0813,129.1023,276.1544,258.1439 \\
\quad 257.1604\end{array}$ & $\beta-$ & $8.89 \pm 1.85$ & $5.50 \pm 0.46$ \\
\hline 51 & $\mathrm{EL}$ & 3.80 & 261.1446 & -0.568 & $\mathrm{C}_{11} \mathrm{H}_{21} \mathrm{O}_{5} \mathrm{~N}_{2}$ & $\begin{array}{l}86.0969,132.1019,84.045,261.1443 \\
\quad 198.1123\end{array}$ & $\beta-$ & $2.40 \pm 1.02$ & $4.97 \pm 0.47$ \\
\hline 52 & FA & 3.88 & 237.1231 & -0.965 & $\mathrm{C}_{12} \mathrm{H}_{17} \mathrm{O}_{3} \mathrm{~N}_{2}$ & $\begin{array}{l}120.0809,121.0844,237.1231,86.0969 \\
72.0815\end{array}$ & $\beta-$ & $37.83 \pm 11.07$ & $53.68 \pm 3.61$ \\
\hline 53 & $\mathrm{FF}$ & 6.49 & 313.1542 & -0.891 & $\mathrm{C}_{18} \mathrm{H}_{21} \mathrm{O}_{3} \mathrm{~N}_{2}$ & $\begin{array}{l}120.0809,121.0843,313.1544,166.0863 \\
103.0547\end{array}$ & $\beta-$ & $4.91 \pm 1.23$ & $23.36 \pm 1.91$ \\
\hline 54 & FFE & 5.82 & 442.1970 & -0.615 & $\mathrm{C}_{23} \mathrm{H}_{28} \mathrm{O}_{6} \mathrm{~N}_{3}$ & $\begin{array}{l}120.0809,442.1970,267.1488,295.1471 \\
121.0844\end{array}$ & $\beta-$ & $3.35 \pm 0.91$ & $35.23 \pm 2.92$ \\
\hline 55 & FG & 4.00 & 223.1072 & -2.281 & $\mathrm{C}_{11} \mathrm{H}_{15} \mathrm{O}_{3} \mathrm{~N}_{2}$ & $\begin{array}{l}120.0809,84.0814,294.1812,147.1128 \\
129.1023\end{array}$ & $\beta-$ & $1.86 \pm 0.56$ & $1.64 \pm 0.11$ \\
\hline 56 & FK & 1.72 & 294.1812 & -0.232 & $\mathrm{C}_{15} \mathrm{H}_{24} \mathrm{O}_{3} \mathrm{~N}_{3}$ & $\begin{array}{l}120.0809,84.0814,294.1812,147.1128 \\
\quad 129.1023\end{array}$ & $\alpha-$ & $9.36 \pm 3.11$ & $3.57 \pm 0.27$ \\
\hline 57 & FL & 6.00 & 279.1701 & 0.003 & $\mathrm{C}_{15} \mathrm{H}_{23} \mathrm{O}_{3} \mathrm{~N}_{2}$ & $\begin{array}{l}86.0969,69.0706,120.0809,279.1703 \\
\quad 166.0862\end{array}$ & $a-$ & $4.00 \pm 1.14$ & $54.7 \pm 2.58$ \\
\hline 58 & FLA & 6.68 & 350.2072 & -0.636 & $\mathrm{C}_{18} \mathrm{H}_{28} \mathrm{O}_{4} \mathrm{~N}_{3}$ & $\begin{array}{l}120.0809,86.0969,219.1126,191.1177 \\
132.1019\end{array}$ & $\alpha-$ & $0.77 \pm 0.27$ & $2.05 \pm 0.16$ \\
\hline 59 & FLG & 6.58 & 336.1912 & -2.745 & $\mathrm{C}_{17} \mathrm{H}_{26} \mathrm{O}_{4} \mathrm{~N}_{3}$ & $\begin{array}{l}120.0809,177.1021,205.0972,86.0969 \\
121.0844\end{array}$ & $\alpha-$ & $0.48 \pm 0.13$ & $1.06 \pm 0.17$ \\
\hline 60 & $\mathrm{FN}$ & 2.43 & 280.1289 & -1.187 & $\mathrm{C}_{13} \mathrm{H}_{18} \mathrm{O}_{4} \mathrm{~N}_{3}$ & $\begin{array}{l}120.0809,133.0608,121.0843,263.1020 \\
280.1288\end{array}$ & $\alpha-; \beta-$ & $13.25 \pm 4.33$ & $16.98 \pm 1.26$ \\
\hline 61 & FNL & 6.45 & 393.2126 & -1.593 & $\mathrm{C}_{19} \mathrm{H}_{29} \mathrm{O}_{5} \mathrm{~N}_{4}$ & $\begin{array}{l}120.0809,262.1183,393.2126,217.097 \\
\quad 121.0843\end{array}$ & $\alpha-$ & $9.49 \pm 2.51$ & $21.12 \pm 1.42$ \\
\hline 62 & FP & 5.64 & 263.1387 & -1.098 & $\mathrm{C}_{14} \mathrm{H}_{19} \mathrm{O}_{3} \mathrm{~N}_{2}$ & $\begin{array}{l}120.0809,116.0708,70.0658,263.1387 \\
86.0969\end{array}$ & $\alpha-$ & $14.55 \pm 3.71$ & $12.11 \pm 0.91$ \\
\hline
\end{tabular}


Table S4 Qualitative and quantitative analysis results of di-/tripeptides in hydrolysates ${ }^{1}-$ Continued

\begin{tabular}{|c|c|c|c|c|c|c|c|c|c|}
\hline \multirow{2}{*}{$\begin{array}{l}\text { Peak } \\
\text { no. }\end{array}$} & \multirow{2}{*}{ Sequence } & \multirow{2}{*}{$\begin{array}{c}\text { Rt } \\
(\min )\end{array}$} & \multirow{2}{*}{$\begin{array}{c}m / z \\
{[\mathbf{M}+\mathbf{H}]^{+}}\end{array}$} & \multirow{2}{*}{$\begin{array}{l}\text { Error } \\
(\mathrm{ppm})\end{array}$} & \multirow{2}{*}{$\begin{array}{l}\text { Molecular } \\
\text { formula }\end{array}$} & \multirow{2}{*}{ MS/MS fragments } & \multirow{2}{*}{$\begin{array}{l}\text { Parent } \\
\text { protein }\end{array}$} & \multicolumn{2}{|c|}{ Concentration $(\mu \mathrm{g} / \mathrm{mL})$} \\
\hline & & & & & & & & РBCH & PBCH-GI \\
\hline$\overline{63}$ & FQK & 1.81 & 422.2390 & -1.789 & $\mathrm{C}_{20} \mathrm{H}_{32} \mathrm{O}_{5} \mathrm{~N}_{5}$ & $\begin{array}{l}120.0809,422.2390,165.1021,84.0813 \\
129.1022\end{array}$ & $\beta-$ & $1.75 \pm 0.70$ & $6.01 \pm 0.76$ \\
\hline 64 & GH & 1.09 & 213.0980 & -0.689 & $\mathrm{C}_{8} \mathrm{H}_{13} \mathrm{O}_{3} \mathrm{~N}_{4}$ & $\begin{array}{l}110.0715,156.0766,213.0981,195.0876 \\
167.0926\end{array}$ & $\alpha-; \beta-$ & $11.46 \pm 2.56$ & $9.11 \pm 0.68$ \\
\hline 65 & GHL & 4.19 & 326.1821 & -0.646 & $\mathrm{C}_{14} \mathrm{H}_{24} \mathrm{O}_{4} \mathrm{~N}_{5}$ & $\begin{array}{l}195.0875,110.0715,122.0714,326.1821 \\
\quad 167.0926\end{array}$ & $\alpha-$ & $0.43 \pm 0.16$ & $0.81 \pm 0.06$ \\
\hline 66 & GK & 1.03 & 204.1341 & -1.068 & $\mathrm{C}_{8} \mathrm{H}_{18} \mathrm{O}_{3} \mathrm{~N}_{3}$ & $\begin{array}{l}84.0813,129.1023,130.0863,204.1340 \\
\quad 147.1127\end{array}$ & $\alpha-; \beta-$ & $34.42 \pm 8.69$ & $37.72 \pm 2.81$ \\
\hline 67 & GKK & 1.04 & 332.2288 & -1.237 & $\mathrm{C}_{14} \mathrm{H}_{30} \mathrm{O}_{4} \mathrm{~N}_{5}$ & $\begin{array}{l}129.1023,84.0813,332.2288,147.1127 \\
\quad 130.0863\end{array}$ & $\beta-$ & $7.12 \pm 2.42$ & $16.5 \pm 1.15$ \\
\hline 68 & GM & 2.04 & 207.0799 & 0.727 & $\mathrm{C}_{7} \mathrm{H}_{15} \mathrm{O}_{3} \mathrm{~N}_{2} \mathrm{~S}$ & $\begin{array}{l}150.0584,113.0712,104.0532,133.0319 \\
\quad 159.0764\end{array}$ & $\beta-$ & $2.8 \pm 0.90$ & $1.93 \pm 0.14$ \\
\hline 69 & GTF & 4.86 & 324.1557 & 0.934 & $\mathrm{C}_{15} \mathrm{H}_{22} \mathrm{O}_{5} \mathrm{~N}_{3}$ & $\begin{array}{l}120.0809,166.0863,159.0765,131.0816 \\
\quad 74.0607\end{array}$ & $\beta-$ & $6.30 \pm 1.68$ & $27.52 \pm 6.60$ \\
\hline 70 & GV & 1.71 & 175.1075 & -1.25 & $\mathrm{C}_{7} \mathrm{H}_{15} \mathrm{O}_{3} \mathrm{~N}_{2}$ & $\begin{array}{l}72.0815,55.0550,73.0847,175.1075 \\
\quad 70.0658\end{array}$ & $\beta-$ & $10.51 \pm 1.81$ & $22.42 \pm 1.76$ \\
\hline 71 & $\mathrm{HAH}$ & 0.99 & 364.1722 & -0.985 & $\mathrm{C}_{15} \mathrm{H}_{22} \mathrm{O}_{4} \mathrm{~N}_{7}$ & $\begin{array}{l}110.0715,156.0767,364.1724,209.1031 \\
\quad 181.1082\end{array}$ & $\alpha-$ & $4.28 \pm 1.15$ & $9.88 \pm 0.81$ \\
\hline 72 & $\mathrm{HF}$ & 2.67 & 303.1448 & -1.079 & $\mathrm{C}_{15} \mathrm{H}_{19} \mathrm{O}_{3} \mathrm{~N}_{4}$ & $\begin{array}{l}110.0716,303.1448,72.0815,285.1327 \\
\quad 83.0610\end{array}$ & $\alpha-$ & $0.70 \pm 0.23$ & $0.85 \pm 0.09$ \\
\hline 73 & $\mathrm{HH}$ & 1.02 & 293.1356 & -0.221 & $\mathrm{C}_{12} \mathrm{H}_{17} \mathrm{O}_{3} \mathrm{~N}_{6}$ & $\begin{array}{l}110.0716,156.0767,292.6503,84.0814 \\
293.1528\end{array}$ & $\alpha-$ & $1.79 \pm 0.37$ & $0.84 \pm 0.10$ \\
\hline 74 & $\mathrm{HK}$ & 1.01 & 284.1713 & -1.605 & $\mathrm{C}_{12} \mathrm{H}_{22} \mathrm{O}_{3} \mathrm{~N}_{5}$ & $\begin{array}{l}110.0715,284.1713,156.0767,84.0813 \\
266.1605\end{array}$ & $\alpha-; \beta-$ & $4.37 \pm 1.29$ & $7.05 \pm 0.53$ \\
\hline 75 & HL & 1.28 & 269.1605 & -1.104 & $\mathrm{C}_{12} \mathrm{H}_{21} \mathrm{O}_{3} \mathrm{~N}_{4}$ & $\begin{array}{l}110.0715,269.1605,156.0767,251.1499 \\
223.1549\end{array}$ & $\alpha-; \beta-$ & $36.83 \pm 7.81$ & $22.65 \pm 17.40$ \\
\hline 76 & HLS & 3.98 & 356.1919 & -0.857 & $\mathrm{C}_{15} \mathrm{H}_{26} \mathrm{O}_{5} \mathrm{~N}_{5}$ & $\begin{array}{l}110.0715,356.1925,223.1552,251.1498 \\
\quad 129.1022\end{array}$ & $\beta-$ & $1.70 \pm 0.52$ & $2.65 \pm 0.17$ \\
\hline 77 & HP & 4.08 & 253.1293 & -0.857 & $\mathrm{C}_{11} \mathrm{H}_{17} \mathrm{O}_{3} \mathrm{~N}_{4}$ & $\begin{array}{l}156.0767,110.0715,70.0658,235.1187 \\
\quad 253.129\end{array}$ & $\alpha-$ & $1.83 \pm 0.52$ & $1.69 \pm 0.21$ \\
\hline 78 & KFL & 5.52 & 407.2649 & -1.036 & $\mathrm{C}_{21} \mathrm{H}_{35} \mathrm{O}_{4} \mathrm{~N}_{4}$ & $\begin{array}{l}84.0813,129.1023,407.2649,120.0809 \\
\quad 86.0968\end{array}$ & $\alpha-$ & $1.77 \pm 0.51$ & $2.16 \pm 0.16$ \\
\hline 79 & KHL & 1.25 & 397.2554 & -0.881 & $\mathrm{C}_{18} \mathrm{H}_{33} \mathrm{O}_{4} \mathrm{~N}_{6}$ & $\begin{array}{l}\text { 110.0714, 156.0766, 72.0814, 383.203 } \\
\quad 84.0812\end{array}$ & $\beta-$ & $6.87 \pm 1.85$ & $10.76 \pm 0.80$ \\
\hline 80 & $\mathrm{KL}$ & 1.28 & 260.1967 & -0.569 & $\mathrm{C}_{12} \mathrm{H}_{26} \mathrm{O}_{3} \mathrm{~N}_{3}$ & $\begin{array}{l}84.0813,260.1968,129.1024,243.1702 \\
\quad 147.1128\end{array}$ & $\alpha-; \beta-$ & $11.64 \pm 2.70$ & $13.92 \pm 1.10$ \\
\hline 81 & KLL & 5.17 & 373.2806 & -0.783 & $\mathrm{C}_{18} \mathrm{H}_{37} \mathrm{O}_{4} \mathrm{~N}_{4}$ & $\begin{array}{l}84.0813,129.1024,373.2806,86.0970 \\
\quad 185.0556\end{array}$ & $\alpha-$ & $1.01 \pm 0.29$ & $17.99 \pm 1.31$ \\
\hline 82 & KT & 1.06 & 248.1603 & -0.655 & $\mathrm{C}_{10} \mathrm{H}_{22} \mathrm{O}_{4} \mathrm{~N}_{3}$ & $\begin{array}{l}84.0813,129.1023,248.1603,130.0863 \\
\quad 74.0607\end{array}$ & $\alpha-$ & $17.45 \pm 4.09$ & $25.36 \pm 2.04$ \\
\hline 83 & KVV & 2.25 & 345.2494 & -0.788 & $\mathrm{C}_{16} \mathrm{H}_{33} \mathrm{O}_{4} \mathrm{~N}_{4}$ & $\begin{array}{l}\text { 72.0815, 84.0814, 129.1024, 171.1491, } \\
\quad 199.1441\end{array}$ & $\beta-$ & $3.24 \pm 1.35$ & $4.51 \pm 0.31$ \\
\hline 84 & $\mathrm{KY}$ & 2.48 & 310.1759 & -0.847 & $\mathrm{C}_{15} \mathrm{H}_{24} \mathrm{O}_{4} \mathrm{~N}_{3}$ & $\begin{array}{l}84.0813,310.1759,129.1023,136.0757 \\
\quad 84.0449\end{array}$ & $\alpha-; \beta-$ & $5.02 \pm 1.13$ & $4.87 \pm 0.38$ \\
\hline 85 & LAA & 4.66 & 274.1761 & -0.046 & $\mathrm{C}_{12} \mathrm{H}_{24} \mathrm{O}_{4} \mathrm{~N}_{3}$ & $\begin{array}{l}115.0868,143.0815,86.0969,132.1019 \\
203.1391\end{array}$ & $\alpha-$ & $1.95 \pm 0.65$ & $4.37 \pm 0.37$ \\
\hline 86 & LAH & 2.78 & 340.1977 & -0.796 & $\mathrm{C}_{15} \mathrm{H}_{26} \mathrm{O}_{4} \mathrm{~N}_{5}$ & $\begin{array}{l}110.0715,340.1977,209.1031,181.1083 \\
\quad 136.0868\end{array}$ & $\beta-$ & $1.18 \pm 0.37$ & $2.01 \pm 0.16$ \\
\hline 87 & LAL & 6.06 & 316.2226 & -1.527 & $\mathrm{C}_{15} \mathrm{H}_{30} \mathrm{O}_{4} \mathrm{~N}_{3}$ & $\begin{array}{l}86.0969,157.1335,185.1284,87.1001 \\
\quad 132.1020\end{array}$ & $\beta-$ & $4.98 \pm 1.35$ & $10.39 \pm 0.56$ \\
\hline 88 & LDK & 1.89 & 375.2239 & 0.104 & $\mathrm{C}_{16} \mathrm{H}_{31} \mathrm{O}_{6} \mathrm{~N}_{4}$ & $\begin{array}{l}375.2238,84.0813,201.1232,86.0970 \\
\quad 147.1128\end{array}$ & $\alpha-$ & $10.09 \pm 3.46$ & $1.78 \pm 0.16$ \\
\hline 89 & LGH & 2.06 & 326.1821 & -0.646 & $\mathrm{C}_{14} \mathrm{H}_{24} \mathrm{O}_{4} \mathrm{~N}_{5}$ & $\begin{array}{l}195.0876,110.0715,122.0714,178.0609 \\
\quad 326.1821\end{array}$ & $\beta-$ & $25.70 \pm 6.96$ & $28.45 \pm 7.10$ \\
\hline 90 & LGR & 2.63 & 345.2242 & -0.782 & $\mathrm{C}_{14} \mathrm{H}_{29} \mathrm{O}_{4} \mathrm{~N}_{6}$ & $\begin{array}{l}345.2242,232.1403,72.0815,70.0658 \\
\quad 171.1490\end{array}$ & $\beta-$ & $1.39 \pm 0.49$ & $5.93 \pm 0.46$ \\
\hline 91 & LHV & 4.78 & 368.2291 & -0.355 & $\mathrm{C}_{17} \mathrm{H}_{30} \mathrm{O}_{4} \mathrm{~N}_{5}$ & $\begin{array}{l}110.0716,368.2291,237.1344,166.0610 \\
269.1606\end{array}$ & $\beta-$ & $6.82 \pm 2.02$ & $16.52 \pm 1.28$ \\
\hline 92 & LKG & 1.68 & 317.2183 & -0.227 & $\mathrm{C}_{14} \mathrm{H}_{29} \mathrm{O}_{4} \mathrm{~N}_{4}$ & $\begin{array}{l}70.0658,84.0813,129.1023,60.0452 \\
\quad 117.0661\end{array}$ & $\beta-$ & $1.51 \pm 0.55$ & $1.08 \pm 0.08$ \\
\hline 93 & LLV & 6.56 & 344.2542 & -0.59 & $\mathrm{C}_{17} \mathrm{H}_{34} \mathrm{O}_{4} \mathrm{~N}_{3}$ & $\begin{array}{l}86.0969,72.0814,185.1648,213.1596 \\
\quad 344.2542\end{array}$ & $\alpha-; \beta-$ & $4.49 \pm 1.29$ & $10.00 \pm 5.55$ \\
\hline
\end{tabular}


Table S4 Qualitative and quantitative analysis results of di-/tripeptides in hydrolysates ${ }^{1}-$ Continued

\begin{tabular}{|c|c|c|c|c|c|c|c|c|c|}
\hline \multirow{2}{*}{$\begin{array}{l}\text { Peak } \\
\text { no. }\end{array}$} & \multirow{2}{*}{ Sequence } & \multirow{2}{*}{$\begin{array}{c}\text { Rt } \\
(\min )\end{array}$} & \multirow{2}{*}{$\begin{array}{c}m / z \\
{[\mathbf{M}+\mathbf{H}]^{+}}\end{array}$} & \multirow{2}{*}{$\begin{array}{l}\text { Error } \\
(\mathrm{ppm})\end{array}$} & \multirow{2}{*}{$\begin{array}{l}\text { Molecular } \\
\text { formula }\end{array}$} & \multirow{2}{*}{ MS/MS fragments } & \multirow{2}{*}{$\begin{array}{l}\text { Parent } \\
\text { protein }\end{array}$} & \multicolumn{2}{|c|}{ Concentration $(\mu \mathrm{g} / \mathrm{mL})$} \\
\hline & & & & & & & & РBCH & PBCH-GI \\
\hline 94 & LP & 4.49 & 229.1546 & -0.301 & $\mathrm{C}_{11} \mathrm{H}_{21} \mathrm{O}_{3} \mathrm{~N}_{2}$ & $\begin{array}{l}\text { 70.0658, 229.1546, 116.0707, 120.081, } \\
\quad 71.0691\end{array}$ & $a-$ & $17.21 \pm 4.70$ & $14.9 \pm 1.15$ \\
\hline 95 & LPG & 4.14 & 286.1758 & -1.023 & $\mathrm{C}_{13} \mathrm{H}_{24} \mathrm{O}_{4} \mathrm{~N}_{3}$ & $\begin{array}{l}173.0921,70.0658,86.0969,286.1758 \\
\quad 174.0959\end{array}$ & $\alpha-$ & $4.01 \pm 1.12$ & $1.92 \pm 0.15$ \\
\hline 96 & LQ & 1.29 & 260.1606 & 0.605 & $\mathrm{C}_{11} \mathrm{H}_{22} \mathrm{O}_{4} \mathrm{~N}_{3}$ & $\begin{array}{l}86.0969,147.0764,130.05,260.1606 \\
\quad 84.0449\end{array}$ & $\beta-$ & $10.61 \pm 3.02$ & $10.84 \pm 0.83$ \\
\hline 97 & LRV & 2.10 & 387.2708 & -1.524 & $\mathrm{C}_{17} \mathrm{H}_{35} \mathrm{O}_{4} \mathrm{~N}_{6}$ & $\begin{array}{l}387.2708,86.0969,175.1188,72.0814 \\
\quad 84.0812\end{array}$ & $\alpha-$ & $0.35 \pm 0.16$ & $2.22 \pm 0.55$ \\
\hline 98 & LW & 6.40 & 318.1810 & -0.591 & $\mathrm{C}_{17} \mathrm{H}_{24} \mathrm{O}_{3} \mathrm{~N}_{3}$ & $\begin{array}{l}86.0969,188.0705,205.0971,318.1810 \\
\quad 146.0599\end{array}$ & $\beta-$ & $13.64 \pm 3.50$ & $33.44 \pm 3.05$ \\
\hline 99 & MF & 5.88 & 297.1262 & -1.749 & $\mathrm{C}_{14} \mathrm{H}_{21} \mathrm{O}_{3} \mathrm{~N}_{2} \mathrm{~S}$ & $\begin{array}{l}\text { 104.0532, 56.0503, 61.0114, } 120.0810 \\
\quad 297.1262\end{array}$ & $\alpha-$ & $1.26 \pm 0.27$ & $9.34 \pm 0.75$ \\
\hline 100 & MFL & 3.84 & 410.2109 & 0.235 & $\mathrm{C}_{20} \mathrm{H}_{32} \mathrm{O}_{4} \mathrm{~N}_{3} \mathrm{~S}$ & $\begin{array}{l}129.1022,84.0813,409.2097,128.1070 \\
86.0969\end{array}$ & $\alpha-$ & $3.84 \pm 1.29$ & $3.97 \pm 0.26$ \\
\hline 101 & NAL & 4.41 & 317.1822 & 0.674 & $\mathrm{C}_{13} \mathrm{H}_{25} \mathrm{O}_{5} \mathrm{~N}_{4}$ & $\begin{array}{l}158.0923,186.0873,86.0969,124.0395 \\
\quad 141.0658\end{array}$ & $\beta-$ & $23.86 \pm 5.94$ & $59.15 \pm 4.33$ \\
\hline 102 & NF & 4.54 & 280.1291 & -0.33 & $\mathrm{C}_{13} \mathrm{H}_{18} \mathrm{O}_{4} \mathrm{~N}_{3}$ & $\begin{array}{l}200.0703,246.0756,120.0809,175.0865 \\
\quad 87.0558\end{array}$ & $\alpha-; \beta-$ & $35.9 \pm 9.51$ & $69.31 \pm 5.00$ \\
\hline 103 & NFK & 2.07 & 408.2242 & 0.231 & $\mathrm{C}_{19} \mathrm{H}_{30} \mathrm{O}_{5} \mathrm{~N}_{5}$ & $\begin{array}{l}\text { 408.2242, } 120.0809,84.0813,147.1128 \\
\quad 234.1236\end{array}$ & $\alpha-$ & $12.15 \pm 2.63$ & $33.34 \pm 9.32$ \\
\hline 104 & NFR & 2.60 & 436.2297 & -0.331 & $\mathrm{C}_{19} \mathrm{H}_{38} \mathrm{O}_{4} \mathrm{~N}_{3}$ & $\begin{array}{l}436.2300,120.081,437.2333,70.0658 \\
\quad 175.1189\end{array}$ & $\beta-$ & $4.85 \pm 1.62$ & $16.33 \pm 1.27$ \\
\hline 105 & NLK & 1.75 & 374.2399 & 0.199 & $\mathrm{C}_{16} \mathrm{H}_{32} \mathrm{O}_{5} \mathrm{~N}_{5}$ & $\begin{array}{l}374.2399,86.0969,84.0814,200.1393 \\
\quad 147.1128\end{array}$ & $\beta-$ & $9.04 \pm 2.89$ & $31.27 \pm 2.02$ \\
\hline 106 & NVK & 1.24 & 360.2240 & -0.487 & $\mathrm{C}_{15} \mathrm{H}_{30} \mathrm{O}_{5} \mathrm{~N}_{5}$ & $\begin{array}{l}360.2240,84.0813,72.0814,186.1236 \\
\quad 129.1023\end{array}$ & $\alpha-$ & $22.21 \pm 6.84$ & $43.84 \pm 3.19$ \\
\hline 107 & $\mathrm{PD}$ & 4.39 & 231.0974 & -0.511 & $\mathrm{C}_{9} \mathrm{H}_{15} \mathrm{O}_{5} \mathrm{~N}_{2}$ & $\begin{array}{l}\text { 70.0658, 231.0974, 71.0691, 232.1004, } \\
\quad 72.0814\end{array}$ & $\alpha-; \beta-$ & $1.08 \pm 0.24$ & $0.94 \pm 0.06$ \\
\hline 108 & $\mathrm{PE}$ & 2.45 & 245.1129 & -1.094 & $\mathrm{C}_{10} \mathrm{H}_{17} \mathrm{O}_{5} \mathrm{~N}_{2}$ & $\begin{array}{l}70.0658,245.1129,86.0970,72.0815 \\
\quad 84.0814\end{array}$ & $\beta-$ & $3.05 \pm 0.74$ & $3.30 \pm 0.30$ \\
\hline 109 & PKV & 3.02 & 343.2337 & -0.18 & $\mathrm{C}_{16} \mathrm{H}_{31} \mathrm{O}_{4} \mathrm{~N}_{4}$ & $\begin{array}{l}84.0814,129.1024,70.0658,343.2339 \\
\quad 72.0815\end{array}$ & $\beta-$ & $23.26 \pm 8.37$ & $1.61 \pm 0.14$ \\
\hline 110 & PS & 4.22 & 203.1022 & -1.986 & $\mathrm{C}_{8} \mathrm{H}_{15} \mathrm{O}_{4} \mathrm{~N}_{2}$ & $\begin{array}{l}\text { 70.0658, 132.1020, 86.0970, 203.1022, } \\
\quad 157.1336\end{array}$ & $\alpha-$ & $4.23 \pm 1.16$ & $4.56 \pm 0.56$ \\
\hline 111 & PT & 1.60 & 217.1184 & 0.352 & $\mathrm{C}_{9} \mathrm{H}_{17} \mathrm{O}_{4} \mathrm{~N}_{2}$ & $\begin{array}{l}70.0658,217.1184,200.1029,84.0449 \\
\quad 90.0554\end{array}$ & $\alpha-$ & $8.23 \pm 2.41$ & $7.42 \pm 0.56$ \\
\hline 112 & PV & 2.13 & 215.1389 & -0.692 & $\mathrm{C}_{10} \mathrm{H}_{19} \mathrm{O}_{3} \mathrm{~N}_{2}$ & $\begin{array}{l}\text { 70.0658, } 215.1389,71.0690,72.0814 \\
\quad 216.1424\end{array}$ & $\alpha-$ & $14.43 \pm 4.57$ & $15.73 \pm 1.22$ \\
\hline 113 & QK & 1.05 & 275.1718 & 1.52 & $\mathrm{C}_{11} \mathrm{H}_{23} \mathrm{O}_{4} \mathrm{~N}_{4}$ & $\begin{array}{l}84.0814,129.1024,258.1441,84.0450 \\
\quad 130.0863\end{array}$ & $\alpha-; \beta-$ & $10.27 \pm 2.61$ & $9.57 \pm 0.8$ \\
\hline 114 & QSF & 4.68 & 381.1770 & 0.365 & $\mathrm{C}_{17} \mathrm{H}_{25} \mathrm{O}_{6} \mathrm{~N}_{4}$ & $\begin{array}{l}120.0810,166.0863,84.0450,83.0610 \\
\quad 363.1662\end{array}$ & $\beta-$ & $1.49 \pm 2.21$ & $1.86 \pm 2.87$ \\
\hline 115 & QVK & 1.25 & 374.2398 & -0.122 & $\mathrm{C}_{16} \mathrm{H}_{32} \mathrm{O}_{5} \mathrm{~N}_{5}$ & $\begin{array}{l}374.2397,182.1288,84.0813,183.1128 \\
\quad 72.0815\end{array}$ & $\alpha-$ & $16.44 \pm 3.91$ & $39.24 \pm 2.83$ \\
\hline 116 & $\mathrm{RF}$ & 1.84 & 322.1873 & -0.143 & $\mathrm{C}_{15} \mathrm{H}_{24} \mathrm{O}_{3} \mathrm{~N}_{5}$ & $\begin{array}{l}322.1873,120.081,175.1189,70.0658 \\
\quad 60.0564\end{array}$ & $\beta-$ & $3.73 \pm 1.29$ & $7.05 \pm 0.59$ \\
\hline 117 & RFF & 5.90 & 469.2553 & -0.938 & $\mathrm{C}_{24} \mathrm{H}_{33} \mathrm{O}_{4} \mathrm{~N}_{6}$ & $\begin{array}{l}469.2553,112.0872,120.0810,259.1552 \\
\quad 322.1871\end{array}$ & $\beta-$ & $4.47 \pm 1.33$ & $11.72 \pm 0.91$ \\
\hline 118 & RLL & 5.21 & 401.2869 & -0.524 & $\mathrm{C}_{18} \mathrm{H}_{37} \mathrm{O}_{4} \mathrm{~N}_{6}$ & $\begin{array}{l}401.2869,70.0659,112.0873,86.0970 \\
\quad 225.1712\end{array}$ & $\beta-$ & $8.23 \pm 2.02$ & $9.30 \pm 0.63$ \\
\hline 119 & $\mathrm{RM}$ & 1.21 & 306.1591 & -1.133 & $\mathrm{C}_{11} \mathrm{H}_{24} \mathrm{O}_{3} \mathrm{~N}_{5} \mathrm{~S}$ & $\begin{array}{l}306.1591,70.0658,175.1189,60.0564 \\
\quad 289.1325\end{array}$ & $\alpha-$ & $6.87 \pm 1.63$ & $9.83 \pm 0.73$ \\
\hline 120 & SAL & 4.45 & 290.1708 & -0.818 & $\mathrm{C}_{12} \mathrm{H}_{24} \mathrm{O}_{5} \mathrm{~N}_{3}$ & $\begin{array}{l}131.0816,159.0764,86.0970,60.0452 \\
\quad 132.1019\end{array}$ & $\alpha-$ & $31.13 \pm 8.24$ & $68.37 \pm 5.1$ \\
\hline 121 & SH & 1.16 & 243.1086 & -0.952 & $\mathrm{C}_{9} \mathrm{H}_{15} \mathrm{O}_{4} \mathrm{~N}_{4}$ & $\begin{array}{l}110.0715,156.0767,225.0980,243.1086 \\
\quad 70.0658\end{array}$ & $\alpha-$ & $8.92 \pm 2.02$ & $8.72 \pm 0.76$ \\
\hline 122 & $\mathrm{TF}$ & 4.83 & 267.1339 & -0.313 & $\mathrm{C}_{13} \mathrm{H}_{19} \mathrm{O}_{4} \mathrm{~N}_{2}$ & $\begin{array}{l}\text { 74.0607, 120.0809, 166.0861, 267.1339, } \\
56.0503\end{array}$ & $\beta-$ & $9.23 \pm 2.83$ & $22.49 \pm 1.53$ \\
\hline 123 & TLA & 4.69 & 304.1863 & -1.306 & $\mathrm{C}_{13} \mathrm{H}_{26} \mathrm{O}_{5} \mathrm{~N}_{3}$ & $\begin{array}{l}\text { 145.0971, 173.092, 74.0607, 86.0969, } \\
\quad 132.1020\end{array}$ & $\alpha-$ & $1.48 \pm 0.51$ & $4.84 \pm 0.37$ \\
\hline 124 & TQ & 1.22 & 248.1237 & -1.641 & $\mathrm{C}_{9} \mathrm{H}_{18} \mathrm{O}_{5} \mathrm{~N}_{3}$ & $\begin{array}{l}\text { 74.0607, 130.0499, 147.0763, 84.0449, } \\
\quad 248.1237\end{array}$ & $\beta-$ & $10.13 \pm 2.07$ & $15.46 \pm 1.11$ \\
\hline
\end{tabular}


Table S4 Qualitative and quantitative analysis results of di-/tripeptides in hydrolysates ${ }^{1}$ - Continued

\begin{tabular}{|c|c|c|c|c|c|c|c|c|c|}
\hline \multirow{2}{*}{$\begin{array}{l}\text { Peak } \\
\text { no. }\end{array}$} & \multirow{2}{*}{ Sequence } & \multirow{2}{*}{$\begin{array}{c}\text { Rt } \\
(\min )\end{array}$} & \multirow{2}{*}{$\begin{array}{c}m / z \\
{[\mathbf{M}+\mathbf{H}]^{+}}\end{array}$} & \multirow{2}{*}{$\begin{array}{l}\text { Error } \\
(\mathrm{ppm})\end{array}$} & \multirow{2}{*}{$\begin{array}{l}\text { Molecular } \\
\text { formula }\end{array}$} & \multirow{2}{*}{ MS/MS fragments } & \multirow{2}{*}{$\begin{array}{l}\text { Parent } \\
\text { protein }\end{array}$} & \multicolumn{2}{|c|}{ Concentration $(\mu \mathrm{g} / \mathrm{mL})$} \\
\hline & & & & & & & & PBCH & PBCH-GI \\
\hline 125 & TY & 2.70 & 283.1289 & 0.218 & $\mathrm{C}_{13} \mathrm{H}_{19} \mathrm{O}_{5} \mathrm{~N}_{2}$ & $\begin{array}{l}74.0607,182.0810,136.0757,283.1289 \\
\quad 165.0545\end{array}$ & $\alpha-$ & $4.70 \pm 1.45$ & $9.75 \pm 0.71$ \\
\hline 126 & $\mathrm{VH}$ & 1.19 & 255.1449 & -1.164 & $\mathrm{C}_{11} \mathrm{H}_{19} \mathrm{O}_{3} \mathrm{~N}_{4}$ & $\begin{array}{l}156.0767,110.0716,255.1449,72.0815 \\
237.1343\end{array}$ & $\alpha-; \beta-$ & $17.91 \pm 5.08$ & $35.03 \pm 2.74$ \\
\hline 127 & VK & 1.25 & 246.1812 & -0.277 & $\mathrm{C}_{11} \mathrm{H}_{24} \mathrm{O}_{3} \mathrm{~N}_{3}$ & $\begin{array}{l}147.0764,72.0814,84.0813,130.0499 \\
246.1812\end{array}$ & $\alpha-; \beta-$ & $36.7 \pm 9.62$ & $48.71 \pm 3.45$ \\
\hline 128 & VLG & 5.48 & 288.1920 & 0.823 & $\mathrm{C}_{13} \mathrm{H}_{26} \mathrm{O}_{4} \mathrm{~N}_{3}$ & $\begin{array}{l}129.1023,72.0815,157.0972,86.0969 \\
\quad 132.1019\end{array}$ & $\beta-$ & $4.42 \pm 1.28$ & $5.77 \pm 0.45$ \\
\hline 129 & VLQ & 3.38 & 359.2286 & -0.798 & $\mathrm{C}_{16} \mathrm{H}_{31} \mathrm{O}_{5} \mathrm{~N}_{4}$ & $\begin{array}{l}147.0764,130.0500,86.0969,72.0815 \\
\quad 185.1648\end{array}$ & $\beta-$ & $11.23 \pm 3.62$ & $54.64 \pm 4.11$ \\
\hline 130 & VLS & 5.44 & 318.2019 & -1.406 & $\mathrm{C}_{14} \mathrm{H}_{28} \mathrm{O}_{5} \mathrm{~N}_{3}$ & $\begin{array}{l}159.1128,72.0815,187.1076,114.0916 \\
\quad 60.0451\end{array}$ & $\alpha-$ & $2.43 \pm 0.60$ & $7.51 \pm 0.54$ \\
\hline 131 & $\mathrm{VN}$ & 1.27 & 232.1289 & -1.217 & $\mathrm{C}_{9} \mathrm{H}_{18} \mathrm{O}_{4} \mathrm{~N}_{3}$ & $\begin{array}{l}\text { 72.0815, 133.0609, 55.0550, 70.0658 } \\
215.1025\end{array}$ & $\alpha-; \beta-$ & $32.91 \pm 11.23$ & $41.65 \pm 1.83$ \\
\hline 132 & VNF & 5.65 & 379.1979 & 0.827 & $\mathrm{C}_{18} \mathrm{H}_{27} \mathrm{O}_{5} \mathrm{~N}_{4}$ & $\begin{array}{l}72.0815,214.1186,379.1979,86.0969 \\
\quad 120.0811\end{array}$ & $\alpha-$ & $2.32 \pm 0.97$ & $4.11 \pm 0.97$ \\
\hline 133 & VTL & 5.83 & 332.2177 & -0.775 & $\mathrm{C}_{15} \mathrm{H}_{30} \mathrm{O}_{5} \mathrm{~N}_{3}$ & $\begin{array}{l}\text { 72.0815, 201.1233, 74.0607, 173.1284, } \\
\quad 233.1495\end{array}$ & $\alpha-$ & $0.37 \pm 0.1$ & $1.20 \pm 0.08$ \\
\hline 134 & VVA & 3.08 & 288.1912 & -1.918 & $\mathrm{C}_{13} \mathrm{H}_{26} \mathrm{O}_{4} \mathrm{~N}_{3}$ & $\begin{array}{l}\text { 72.0814, 171.1490, 199.1440, 189.123, } \\
\quad 73.0847\end{array}$ & $\beta-$ & $18.19 \pm 5.14$ & $50.7 \pm 3.97$ \\
\hline 135 & VVL & 5.89 & 330.2383 & -1.281 & $\mathrm{C}_{16} \mathrm{H}_{32} \mathrm{O}_{4} \mathrm{~N}_{3}$ & $\begin{array}{l}\text { 72.0815, 171.1491, 199.1440, 86.0969, } \\
172.1529\end{array}$ & $\beta-$ & $18.24 \pm 6.26$ & $48.47 \pm 3.62$ \\
\hline 136 & VY & 3.67 & 281.1493 & -1.044 & $\mathrm{C}_{14} \mathrm{H}_{21} \mathrm{O}_{4} \mathrm{~N}_{2}$ & $\begin{array}{l}72.0814,182.0810,136.0757,55.0550 \\
\quad 120.0809\end{array}$ & $\beta-$ & $3.82 \pm 1.21$ & $4.54 \pm 0.32$ \\
\hline 137 & VYP & 4.71 & 378.2023 & -0.125 & $\mathrm{C}_{19} \mathrm{H}_{28} \mathrm{O}_{5} \mathrm{~N}_{3}$ & $\begin{array}{l}136.0757,116.0709,72.0815,235.1438 \\
263.1390\end{array}$ & $\beta-$ & $4.91 \pm 1.59$ & $4.77 \pm 0.32$ \\
\hline 138 & WG & 4.77 & 262.1188 & 0.695 & $\mathrm{C}_{13} \mathrm{H}_{16} \mathrm{O}_{3} \mathrm{~N}_{3}$ & $\begin{array}{l}245.0919,159.0916,144.0808,132.0808 \\
\quad 170.0599\end{array}$ & $\alpha-; \beta-$ & $4.04 \pm 1.14$ & $3.66 \pm 0.28$ \\
\hline 139 & WGK & 3.11 & 390.2137 & 0.177 & $\mathrm{C}_{19} \mathrm{H}_{28} \mathrm{O}_{4} \mathrm{~N}_{5}$ & $\begin{array}{l}390.2137,159.0917,84.0813,86.0969 \\
\quad 72.0814\end{array}$ & $\alpha-; \beta-$ & $19.29 \pm 6.94$ & $76.27 \pm 5.84$ \\
\hline 140 & YF & 5.71 & 329.1496 & -0.041 & $\mathrm{C}_{18} \mathrm{H}_{21} \mathrm{O}_{4} \mathrm{~N}_{2}$ & $\begin{array}{l}136.0757,86.0969,72.0815,213.1596 \\
\quad 185.1647\end{array}$ & $\alpha-$ & $1.18 \pm 0.32$ & $2.48 \pm 0.18$ \\
\hline 141 & YFP & 5.91 & 426.2013 & -2.833 & $\mathrm{C}_{23} \mathrm{H}_{28} \mathrm{O}_{5} \mathrm{~N}_{3}$ & $\begin{array}{l}136.0757,116.0708,120.0809,70.0658 \\
\quad 311.1387\end{array}$ & $\alpha-$ & $1.7 \pm 0.60$ & $3.18 \pm 0.45$ \\
\hline 142 & $\mathrm{YH}$ & 1.24 & 319.1402 & 0.277 & $\mathrm{C}_{15} \mathrm{H}_{19} \mathrm{O}_{4} \mathrm{~N}_{4}$ & $\begin{array}{l}110.0716,156.0768,319.1402,136.0757 \\
\quad 301.1292\end{array}$ & $\beta-$ & $6.92 \pm 1.85$ & $14.58 \pm 1.14$ \\
\hline 143 & YP & 3.86 & 279.1337 & -0.837 & $\mathrm{C}_{14} \mathrm{H}_{19} \mathrm{O}_{4} \mathrm{~N}_{2}$ & $\begin{array}{l}136.0757,116.0709,70.0658,279.1337 \\
119.0493\end{array}$ & $\beta-$ & $5.22 \pm 1.65$ & $1.72 \pm 0.14$ \\
\hline 144 & YR & 1.26 & 338.1818 & -1.362 & $\mathrm{C}_{15} \mathrm{H}_{24} \mathrm{O}_{4} \mathrm{~N}_{5}$ & $\begin{array}{l}338.1818,136.0756,175.1188,70.0658 \\
339.1844\end{array}$ & $\alpha-$ & $3.19 \pm 0.68$ & $14.65 \pm 1.25$ \\
\hline 145 & AHK & 1.00 & 355.2086 & -0.675 & $\mathrm{C}_{15} \mathrm{H}_{27} \mathrm{O}_{4} \mathrm{~N}_{6}$ & $\begin{array}{l}110.0716,355.2086,209.1031,156.0768 \\
136.0869\end{array}$ & $\alpha-; \beta-$ & ND & $7.00 \pm 0.57$ \\
\hline 146 & ERM & 1.91 & 435.2012 & -0.988 & $\mathrm{C}_{16} \mathrm{H}_{31} \mathrm{O}_{6} \mathrm{~N}_{6} \mathrm{~S}$ & $\begin{array}{l}435.2016,304.1612,70.0658,436.2037 \\
\quad 84.0449\end{array}$ & $\alpha-$ & ND & $0.52 \pm 0.04$ \\
\hline 147 & ESF & 4.84 & 382.1608 & -0.124 & $\mathrm{C}_{17} \mathrm{H}_{24} \mathrm{O}_{7} \mathrm{~N}_{3}$ & $\begin{array}{l}120.0809,166.0862,126.0550,84.0449 \\
110.0715\end{array}$ & $\beta-$ & ND & $1.93 \pm 0.10$ \\
\hline 148 & FAK & 3.21 & 365.2179 & -1.182 & $\mathrm{C}_{18} \mathrm{H}_{29} \mathrm{O}_{4} \mathrm{~N}_{4}$ & $\begin{array}{l}120.0809,365.2179,84.0813,147.1127 \\
130.0863\end{array}$ & $\beta-$ & ND & $0.63 \pm 0.08$ \\
\hline 149 & GR & 1.08 & 232.1401 & -1.404 & $\mathrm{C}_{8} \mathrm{H}_{18} \mathrm{O}_{3} \mathrm{~N}_{5}$ & $\begin{array}{l}232.1401,70.0658,116.0708,100.0509 \\
\quad 215.1137\end{array}$ & $\beta-$ & ND & $7.64 \pm 0.64$ \\
\hline 150 & SV & 1.86 & 205.1184 & 0.665 & $\mathrm{C}_{8} \mathrm{H}_{17} \mathrm{O}_{4} \mathrm{~N}_{2}$ & $\begin{array}{l}60.0451,72.0814,118.0864,159.1127 \\
205.1184\end{array}$ & $\alpha-$ & ND & $41.51 \pm 2.81$ \\
\hline
\end{tabular}

${ }^{1}$ Peak no. 1-144 refer to the small peptides identified in both PBCH and PBCH-GI, no. 145-150 refer to the small peptides only identified in PBCH-GI. a- means porcine hemoglobin (alpha subunit), $\beta$ - means porcine hemoglobin (beta subunit). Concentration are presented as mean $\pm \mathrm{SD}(n=3)$, ND indicates that the peptide is not detected in $\mathrm{PBCH}$. $\mathrm{PBCH}$, pig blood cells hydrolysates; PBCH-GI, gastrointestinal-digested pig blood cells hydrolysates. 